University of St. Thomas, Minnesota

UST Research Online

Finance Faculty Publications

Finance

2018

It pays to partner with a firm that writes annual reports well

Mufaddal H. Baxamusa

University of St Thomas - Saint Paul, baxa0428@stthomas.edu

Abu Jalal

Suffolk University

Follow this and additional works at: https://ir.stthomas.edu/ocbfincpub

Part of the Finance and Financial Management Commons

This Article is brought to you for free and open access by the Finance at UST Research Online. It has been accepted for inclusion in Finance Faculty Publications by an authorized administrator of UST Research Online. For more information, please contact asle4660@stthomas.edu. 


\title{
It pays to partner with a firm that writes annual reports well
}

\author{
Mufaddal Baxamusa, Abu Jalal \& Anand Jha*,¥
}

\section{April 20, 2018}

\begin{abstract}
We use strategic alliances as a setting to examine whether the readability of a firm's partner's 10-

$\mathrm{K}$ matters. We find that the increase in the cumulative abnormal return (CAR) around the announcement of an alliance is relatively lower when the firm's partner in a strategic alliance has a less readable $10-\mathrm{K}$ report. Additional tests show that the impact of the readability of a partner's $10-\mathrm{K}$ is much stronger when investors suspect insufficient due diligence before the alliance's formation, when the partner is from a different industry, and when the alliance occurs before the Sarbanes-Oxley Act. Overall, our results show that the readability of a partner's annual report matters-it pays to partner with a firm that writes these reports well.
\end{abstract}

Key Words: Strategic Alliance, Readability, 10-Ks, Annual Reports

JEL: G02, G32, G14, M41

* Mufaddal Baxamusa is at St. Thomas University, Phone (651) 962-5845, E-mail mufaddalb@stthomas.edu; Abu Jalal is at Suffolk University, Phone (617) 570-4898, E-mail ajalal@suffolk.edu; Anand Jha is at Wayne State University, Phone (313) 577-4539, and E-mail anand.jha@wayne.edu.

$¥$ We thank all of the participants in the seminar series at Texas A\&M International University, Wayne State University, University of Rhode Island, and Suffolk University. We thank Feng Li for making the data on the readability $10-\mathrm{Ks}$ publically available on his website. Earlier version of the paper was circulated with the title "Strategic Alliances and the Readability of 10-Ks". 


\section{Introduction}

Two recent studies show that the readability of 10-Ks affects a firm's value. Hwang and Kim (2017) find that firms whose annual disclosures are less readable trade at a discount. Ertugrul et al. (2017) find that when a firm's $10-\mathrm{K}$ is less readable, its loans have shorter maturities and banks demand higher collateral. These studies indicate that besides quantitative information, investors also incorporate qualitative information (Tetlock, 2007; Tetlock et al., 2008) and that investors' consider less readable 10-Ks as an indicator of a firm's attempt to hide bad news (Li, 2008; Lo et al., 2017).

We build on this stream of literature and ask a question quite different from theirs: Does the readability of a partner's $10-\mathrm{K}$ matter in a strategic alliance? Our research is motivated by studies that find that who a firm associates with can affect its value (Boone and Ivanov, 2012; Cohen et al., 2008; Engelberg et al., 2012; Yael et al., 2007).

Our goal is to use strategic alliances as a setting to investigate whether allying with a partner that writes less readable reports can be costly to the firm. Strategic alliances are collaborative partnerships between two firms where both firms pool their resources to achieve a common objective. ${ }^{1}$ According to a report from the Organization for Economic Co-operation and Development the number of strategic alliances grew from 830 transactions to 4,529 between 1989 and 1999 (see OECD report, Kang and Sakai, 2001). By 2000, many of the big global firms had over $20 \%$ of their assets and 30\% of their research expenditures invested in these alliances (Ernst, 2004). Studies show that over $80 \%$ of the Fortune 1000 CEOs believe that almost $26 \%$ of their revenue can be attributed to strategic alliances (Kale et al., 2009).

\footnotetext{
${ }^{1}$ The following example is illustrative: Federal-Mogul Corporation that is based in Detroit, MI is a leading producer of automotive parts, such as chassis, ignition rings, and pistons. They supply these products to automakers around the world. Johnson Controls is a leading producer of automotive batteries from Milwaukee, WI. In 2007, Federal-Mogul Corporation entered into a strategic partnership with Johnson Controls to add its batteries as part of Federal-Mogul's portfolio of offerings to the automakers. By doing so, Johnson Controls increased its market share and Federal-Mogul provided a more wholesome and integrated set of equipment to automakers.
} 
Strategic alliances are an ideal setting to examine the effect of the readability of a partner's $10-\mathrm{K}$ for the following reasons. First, unlike mergers and acquisitions where the acquirer conducts a thorough valuation of the target, the due diligence before an alliance formation is considerably less. It is not cost effective to conduct a thorough investigation because alliances, in essence, are contracts and each party is expected to fulfill its obligations (Yin and Shanley, 2008). Nevin (2014) notes:

In many cases a full and formal due diligence process may be inappropriate in the early days of alliance...... organizations tend to differ quite markedly in the degree of time and attention they devote to the question of due diligence before they enter an important strategic alliance relationship. The difference is probably most extreme in the cases of the pharmaceutical and biotechnology sectors, where the due diligence can take many months if not as long as year, and the high-tech sector in which due diligence sometimes appears to not have taken place at all (page 115).

Second, investors are quite sensitive to indicators that can affect the likelihood of an alliances' success. This is because strategic alliances have a low chance of success, but when successful they bring considerable wealth to shareholders. Studies show that anywhere from 30 to 70\% fail—they do not deliver what they purport to provide (Bamford et al., 2004). Worse still, one study finds that $50 \%$ of the time, firms withdraw before the alliance's completion (Lunnan and Haugland, 2008), which results in value destruction for shareholders (Kale et al., 2002). Despite such higher failure rates, alliances overall create value (Amici et al., 2013; Anand and Khanna, 2000; Chan et al., 1997; Chiou and White, 2005)—the stock market has a positive reaction to the announcement of a strategic alliance.

Third, the announcement of strategic alliances, an example of which we present in the online appendix, are generally pro-forma, and serious investors like to read the $10-\mathrm{Ks}$. We find a spike in the interest in $10-\mathrm{Ks}$ once the firms announce an alliance. Figure 1 shows the number of $10-\mathrm{K}$ downloads from the SEC website. The number of downloads on the day of the announcement is almost 53\% more than three days before. 
Together, it appears that if the readability of a partner's $10-\mathrm{K}$ matters, a strategic alliance is a setting in which we are likely to detect this association. Therefore, we ask: does the readability of a partner's 10-K affect the CAR around the announcement of a strategic alliance?

We posit that the CAR around the announcement will be lower when the partner has a less readable annual report. Once the firm announces its alliance, investors attempt to estimate the wealth that the alliance might bring to the shareholders of the firm. Investors, in effect, do a net present value (NPV) calculation - that is, they estimate the incremental net cash that the alliance might bring and the riskiness of the alliance. Because a less readable document obfuscates this information (Lehavy et al., 2011; Li, 2008) and lowers investors' trust in the partner's character and 10-K (see for e.g., Lev-Ari and Keysar, 2010; Reber et al., 2004; Shah and Oppenheimer, 2007). Lower trust creates a negative sentiment that increases the discount rate and lowers the estimates of future cash flows; the effect of both of these factors is to lower the NPV of the alliance.

To empirically test the effect of the readability of a partner's 10-K report on the firm's CAR around the alliance's announcement, we collect data on strategic alliances from the SDC Platinum database — a database popular for studying strategic alliances. We focus on alliances that involve only two firms. For each announcement, we obtain the CAR for both partners over a five-day window (2, +2). Each announcement results in two observations. For example, if firms A and B form a strategic alliance, then for one observation, $\mathrm{A}$ is the firm and $\mathrm{B}$ is the partner; and for the other, $\mathrm{B}$ is the firm and A is the partner. We add the partner's fog index that is our metric for the readability of annual $10-\mathrm{K}$ reports to this data set. The fog index is a popular metric for measuring the readability of 10-Ks (see e.g., Lee, 2012; Lehavy et al., 2011; Li, 2008; Miller, 2010). These data are available from Feng Li's website. Next, we add the firm-level controls for both the firm and the partner in the alliance. The firm-level data are based on the one year before the announcement of a strategic 
alliance. Then in a multivariate framework, we examine whether the readability of the partner's 10-K report from the previous year affects the CAR of the firm.

We find that the CAR around the alliance announcement is lower when the partner has a less readable 10-K report, which supports our hypothesis. This finding holds for both univariate and multivariate analyses. For example, when we split the sample into two groups based on the median fog index, the CAR at the time of the announcement of the alliance is $1.81 \%$ for a firm with a partner that has a more readable $10-\mathrm{K}$ report; and the CAR is only $0.84 \%$ - a $50 \%$ drop-for a firm with a partner that has a less readable $10-\mathrm{K}$ report. Further, these differences are also statistically significant. A multivariate analysis that controls for a variety of firm-level controls for both the firm and the partner corroborates the univariate results. We continue to find that if the partner has a less readable $10-\mathrm{K}$ report, the CAR is lower for the firm. The economic significance is also large: a change in one standard deviation of readability is associated with a $43 \%$ lower CAR. This association is robust to a wide range of control variables, alternative measures of readability, and alternative windows to measure the firm's CAR. The results are also robust when we use alternative methods such as propensity score matching. What is more, the adverse effect of partner's $10-\mathrm{K}$ readability is much stronger when the number of downloads for their partner's 10-Ks are higher.

A key concern, as with any regression analysis, is that the correlation is spurious. We conduct a number of tests to alleviate this concern. First, we address whether the negative association between the readability of the partner's $10-\mathrm{K}$ report and the CAR is because we assume a linear relation between them. We re-test our hypothesis using propensity score matching, which is a nonparametric method. This method does not assume any sort of relation between the dependent variable and the covariates. It is also designed to rule out the possibility of a spurious correlation (Rosenbaum and Rubin, 1983). Our results continue to hold when we use this method. Second, we examine if the extent to which the partner's $10-\mathrm{K}$ was downloaded from the SEC website 
exacerbates the effect of the partner's $10-\mathrm{K}$ readability on the cumulative abnormal return for the firm. We find that it does - the economic impact of the partner's readability is significantly higher when the $10-\mathrm{K}$ of the firm's partner is downloaded more. Third, we use the SEC's Plain English Initiative (PEI) of 1998 as a shock that suddenly improved the readability of 10 -Ks to conduct a difference-in-difference analysis. This analysis shows that firms that had among the least readable 10-Ks in 1997 significantly improved their readability in 1999, and partnership with these firms did not reduce the cumulative abnormal return of a firm in 1999 to the extent it did in 1997.

Further, we conduct a number of tests to check whether they corroborate our argument. If the results of the additional tests support the explanations we provide on why readability affects the CAR, then the association between the two variables is unlikely to be spurious (Guiso et al., 2008; Guiso et al., 2004). For example, if the readability of a partner's 10-K affects the CAR because it is an indication of the partner's credibility, then the readability's effect on the CAR should be stronger when an alliance involves greater information asymmetry. The idea is that the credibility or lack thereof matters more when operating in a relatively opaque environment. We consider three instances of information asymmetry: when investors suspect insufficient due diligence before forming an alliance, when the partner is from a different industry, and in the pre-SOX period when rules concerning financial reporting were relatively lax. The results largely support this idea.

One of our arguments is that an alliance with a partner that has a less readable $10-\mathrm{K}$ is more likely to abort. We collect data from SDC Platinum on which alliances are withdrawn before their realization and test if the probability of a withdrawal is greater for alliances that have partners with less readable $10-\mathrm{K}$ reports. We find the probability of withdrawal is greater when the partner has a less readable $10-\mathrm{K}$ report.

We also rule out a couple of alternative explanations. One explanation for our results is that it is not the readability per se that affects the CAR but rather the opacity of the partner's financial 
situation. However, this explanation is unlikely because investors focus mainly on estimating the compatibility of the partner with the firm, not the partner's degree of earnings management. Empirical tests support our argument. We find no evidence that the earnings management of the partner affects the CAR around a strategic alliance's announcement. Another possibility is that we are not capturing the effect of the readability of a partner's annual report but rather the poor corporate governance of the partner - that is, the board of directors of some partners might have less control over their CEOs. But that does not appear to be the case either. Our results are robust when we control for the partner's and the firm's corporate governance.

\section{Contribution to the literature}

We add a new perspective to the literature on the readability of $10-\mathrm{Ks}$. We show that not only does the readability of the firm's 10-K report affects investors' perceptions (Ertugrul et al., 2017; Hwang and Kim, 2017), but the readability of a partner's 10-K also affects investors' perceptions - investors punish firms for forming alliances with partners who write less readable 10Ks. By doing so, our study contributes to a nascent but burgeoning stream of research that finds that not only does the quantitative information in the annual reports matter, but the qualitative information in the reports, such as its readability, also matters (e.g., Bonsall and Miller, 2016; Ertugrul et al., 2017; Hwang and Kim, 2017; Laksmana et al., 2012; Lawrence, 2013; Lee, 2012; You and Zhang, 2009). ${ }^{2}$ What makes our study striking is that prior studies have all focused on the firm's $10-\mathrm{K}$ readability, to the best of our knowledge no other study demonstrates that the readability of a partner's $10-\mathrm{K}$ also affects the other firm's value.

Our research complements a number of recent studies that find that a firm's associations can affect its value. For example, Boone and Ivanov (2012) show that when one of the partners in a

2 Some research focuses on other aspects of narration such as ambiguity, tone, and abnormalities in the disclosure (Friberg and Seiler, 2017; Hoberg and Lewis, 2017; Price et al., 2012) 
strategic alliance goes bankrupt, the stock price of the non-bankrupt partner drops. Engelberg et al. (2012) show that when a firm does not have a close interpersonal linkage with banks, it pays a higher interest rate on its loans. Our study shows that not only can an extreme event such as bankruptcy and the lack of a close link hurt a firm but that a mundane aspect of a firm such as the 10-K report's readability can also be detrimental.

We also contribute to the strategic alliance literature. Because we find that the CAR is lower when partner's $10-\mathrm{K}$ is less readable, our study shows that readability might indicate the likelihood of an alliance's success. A large body of literature uses the CAR to measure an alliance's expected success (e.g., Anand and Khanna, 2000; Arino and De La Torre, 1998; Dyer and Singh, 1998; Kale et al., 2001) because it captures the investors' expectation on how much wealth the alliance will bring to the firm's shareholders (Chan et al., 1997). The CAR is also positively correlated with managers' evaluation of the alliance's success ex post (Kale et al., 2001; Kale et al., 2002). Kale et al. (2001) note that in the United States, in "almost 8 out of 10 cases, an alliance that was eventually rated as 'successful' by managers had also been received well by the market when it was first formed/announced (page 464)." Critics might still be skeptical about this conjecture. They might argue that because the readability affects the investor's perception it can affect the CAR of a strategic alliance, but it is unlikely to affect the real success. However, it is possible, as we argue, that a partner that has less readable annual reports is less trustworthy and that forming an alliance with a low trust partner has a higher chance of failure. Indeed, one of our tests shows that a direct measure of success - the probability of an alliance being aborted - is also higher when the partner has a less 
readable report. Given the important role that alliances play in corporate strategy, ${ }^{3}$ this is an economically important contribution.

Our study also has policy and managerial implications. The policy implication of our paper is that the ongoing effort of the SEC to encourage the use of plain English is a good one. By showing that the better readability of $10-\mathrm{Ks}$ is associated with a greater chance of a successful strategic alliance from an investor's perspective, our study finds an alternative channel by which a readable $10-\mathrm{K}$ report can lead to better allocations of capital. The managerial implication of our paper is that the firms should be wary of forming an alliance with firms that have less readable 10-Ks_-investors perceive these alliances as having a lower chance of success.

\section{Related Literature and Hypothesis Development}

In Figure 2, we summarize the mechanism by which the poor readability of a partner's 10-K might affect the CAR around a firm's announcement of its strategic alliance. In the rest of this section, we provide arguments grounded in the literature and empirical evidence to substantiate the thoughts we summarize in Figure 2.

\subsection{Investors will have difficulty understanding the partner's $10-K$ when it is less readable}

The research shows that even experts have difficulty extracting information from annual reports written with long sentences and more complex words. For example, Lehavy et al. (2011) find that when a firm has a less readable $10-\mathrm{K}$ report, an analyst that specializes in the firm's industry has difficulty in analyzing its prospects—-firms with less readable $10-\mathrm{K}$ reports have a larger number of analysts following. These analysts also exert greater effort in preparing reports for these firms. And

\footnotetext{
${ }^{3}$ A strategic alliance is an important aspect of corporate strategy as it is a tool for knowledge transfer (Gomes-Casseres et al., 2006), a vehicle for entering new markets (Robinson, 2008), a mechanism to quickly gain a competitive edge (Deeds and Hill, 1996), a source of alternative financing (Ozmel et al., 2013), and a tool to lower the cost of debt (Chou et al., 2014).
} 
despite this increased effort, the same study finds that the analyst's estimates have greater dispersion and lower accuracy. Lundholm et al. (2014) show that even institutional investors who are trained at going over $10-\mathrm{K}$ reports prefer to invest in foreign firms with clearer reports.

\subsection{When 10-K is less readable, investors trust them less, and consider the managers who wrote those reports less} trustworthy

The developments in various streams of the literature indicate that less readable $10-\mathrm{K}$ reports are associated with poor credibility - that is, investors will trust those documents less and have less faith in the management that produced the report. The psychology literature argues that individuals subconsciously treat feelings of fluency as heuristic cues that the information presented to them can be relied on (Shah and Oppenheimer, 2007). For example, Lev-Ari and Keysar (2010) conduct an experiment where participants judge trivial statements such as "Ants don't sleep" and "A giraffe can go without water longer than a camel can.” Participants judged these statements as less true when a non-native or native with an accent spoke, compared to a native without accent. Reber et al. (2004) propose that when the perceiver can process with ease, his or her aesthetic response is much more positive - they are perceived as more truthful. Summarizing their research, they write:

Multiple theoretical notions converge on the assumption that high fluency is positively marked. The basic idea in all these notions is that high fluency says something about a positive state of affairs, either within the cognitive system or in the world.... High fluency may also feel good because it signals that an external stimulus is familiar, and thus unlikely to be harmful (page 366).

The neuroscience branch of the psychology literature finds an anatomical basis for why cognitive processing is associated with a positive response-the processing of information and the emotional response occur simultaneously in the same parts of the brain (Fernandez-Duque et al., 2000; Lane et al., 1998; LeDoux, 1998).

The recent literature in business also corroborates the findings of psychology. Alter and Oppenheimer (2006) find that in the short run, IPOs with easily pronounceable names outperform 
those with names that are difficult to pronounce. The research in monetary economics also points in a similar direction. In a study that uses similar metrics of readability as we do, Jansen (2011) finds that when the prepared testimony of the central bank's chairperson is more readable, it reduces volatility in the financial market to a great extent. One reason why readable testimony is effective in calming the market is that it is viewed as more credible (Blinder et al., 2008; Winkler, 2000). Rennekamp (2012) shows that investors believe $10-\mathrm{K}$ reports more if the information presented to them is more readable.

Apart from making what is disclosed less believable, poorly written 10-K reports might also send a negative signal about the management's credibility. By credibility, we mean a combined measure of competence-how much someone can trust their claim of competence. The research finds that the fluency of the messenger leads to a positive evaluation of the messenger (Oppenheimer, 2006). In other words, regardless of what the firm reports, investors will perceive the management as more credible if the report is fluent.

There is also some empirical evidence that uses secondary data that shows that readability is associated with less trustworthy behavior. Moffitt and Burns (2009) examine fraudulent and nonfraudulent $10-\mathrm{Ks}$. They find that the $10-\mathrm{Ks}$ of fraudulent firms use more complex words and qualifying conjunctions that make them difficult to read. On the other hand, the $10-\mathrm{Ks}$ of nonfraudulent firms use less complex words and are easier to read.

\subsection{When investors find the partner less trustworthy, they will consider the alliance risky and be pessimistic about the} benefits the alliance will bring

Knowing that many announcements of strategic alliances never even come to realization, and even those that do rarely provide what managers expect them to, investors will critically evaluate the likelihood of the alliance's failure. Investors will also ask questions such as: How reliable is the strength that the partner boasts about in its 10-K? For example, is their foreign presence as good as 
they make it out to be? Will the partner be able to deliver what they promise? Will the partner's managers act opportunistically? Will they comply with regulators and customers while the firm is in alliance with the partner?

Because poor readability of a $10-\mathrm{K}$ affects the perception of a partner's credibility, investors are likely to be skeptical of what they read about the partner's self-assessment of its strength. Investors will also consider these firms to have greater relational risk- the probability that the manager might act opportunistically; greater operational risk-the probability that a partner might fail to meet what was promised.

Investors will also associate a partner with a less readable annual report as having greater compliance risk- the probability that it might fail to meet the customer's, supplier's, or the regulator's expectations (Das and Teng, 2001) and indirectly affect the firm. These indirect effects are not trivial. Overall, investors will increase the discount rate in their calculation of the NPV that they expect the alliance to bring to the firm.

Investors will also be pessimistic about the alliance's future because they will have difficulty understanding exactly how the partner will bring benefits to the firm. This pessimism will lead to investors expecting the alliances to have a shorter life, and lower net cash flow in the future.

3.4. Investors' higher estimates of risk and pessimism about net cash flow from the alliance will lead to a lower estimate of NPV from the alliance and therefore a lower $C A R$

The CAR around an alliance's announcement is in effect a reflection of investors' perception of the NPV the alliance will generate for the firm. Absent a clear picture due to poor readability of $10-\mathrm{K}$ and low credibility, all of the factors that go into the calculation of NPV will be conservativethe expectation of incremental cash that the alliance will be expected to bring to the firm will be lower, the expectation of how long the alliance will last will be shorter, and the expectation on the 
riskiness of the alliance will be greater-all of which will reduce the expected NPV. With a lower expectation on the NPV of the cash the alliance is expected to generate, holding other factors constant, investors will be less likely to buy, and more likely to sell. This behavior will reduce the CAR around the firm's announcement of an alliance.

Based on these arguments, we make the following hypothesis:

Hypothesis: Ceteris paribus, the poorer the readability of the partner's annual 10-K report, the lower the cumulative abnormal stock return is around the announcement of the strategic alliance.

\section{Empirical Model \& Measurement of key variables}

\subsection{Empirical model}

Our purpose is to examine how the readability of the partner's $10-\mathrm{K}$ reports affects the CAR around a strategic alliance's announcement. Therefore, in an alliance with two firms, the dependent variable is from one firm, and the key research variable is from the other. This reasoning can be best understood by the following example. If firms $\mathrm{A}$ and $\mathrm{B}$ form a strategic alliance, then this alliance leads to two observations. One where the dependent variable is the CAR of A, and the key research variable, the readability of the partner's $10-\mathrm{K}$ report, comes from B. And, two, where the dependent variable is the CAR of $B$, and the partner's readability measure comes from A. Given that we examine whether one firm's CAR is affected by the readability of another firm's $10-\mathrm{K}$ report, we need to control for the characteristics of both firms.

The empirical model we use to test our hypothesis is as follows:

$$
\begin{aligned}
& \text { CAR }(-2,+2) \_ \text {firm }= \\
& \beta_{0}+\beta_{1} \text { Fog_partner }+\beta_{2} \text { Fog_firm }+\beta_{3} \operatorname{Ln}\left(\text { assets } \text { firm }_{\text {fir }}+\beta_{4} \mathrm{RO} A_{-} \text {firm }+\beta_{5} \text { Debt-to-assets_firm }+\beta_{6}\right. \text { Market-to- } \\
& \text { book_firm }+\beta_{7} \text { Intangibles_firm }+\beta_{8} R \Theta D \_f i r m+\beta_{9} R \Theta D D \text { Dummy_firm }+\beta_{10} N u m \_o f \_b u s \_s e g \_f i r m+ \\
& \beta_{11} \text { Stock_volatility_firm }+\beta_{12} \text { Social_capital_firm }+\beta_{13} \text { Alliances_exp_firm }+\beta_{14} \text { Number_of_analyst_firm }+\beta_{15} \\
& \text { Analyst_Est._Dispersion_firm }+\beta_{16} L n\left(\text { Assets)_partner }+\beta_{17} \mathrm{ROA} A \text { partner }+\beta_{18} \text { Debt-to-assets_partner }+\right.
\end{aligned}
$$




$$
\begin{aligned}
& \beta_{19} \text { Market-to-book_partner }+\beta_{20} \text { Intangibles_partner }+\beta_{21} R \Theta D \_ \text {partner }+\beta_{22} R \omega D \text { Dummy_partner }+ \\
& \beta_{23} N \text { Num_of_bus_seg_partner }+\beta_{24} \text { Stock_volatility_partner }+\beta_{25} \text { Social_capital_partner }+\beta_{26} \\
& \text { Alliances_exp_partner }+\beta_{27} \text { Alliance_exp_together }+\beta_{28} \text { Number_of_analyst_partner }+\beta_{29} \\
& \text { Analyst_Est._Dispersion_partner }+ \text { Alliance type Indicators }+ \text { Industry indicators }+ \text { Year indictors }+\varepsilon \cdot---(1) .
\end{aligned}
$$

Where,

$$
\begin{aligned}
& \text { CAR }(-2,+2) \text { firm }=\quad \text { the cumulative abnormal stock market return of the firm for a } \\
& \text { window of }(-2,+2) \\
& \text { Fog partner }=\quad \text { the fog index of the partner's } 10-\mathrm{K} \text { report as constructed in }
\end{aligned}
$$$$
(\mathrm{Li}, 2008)
$$

Fog firm $=\quad$ the fog index of the firm's $10-\mathrm{K}$ report as constructed in $(\mathrm{Li}$,

$$
\begin{aligned}
& \text { Ln(assets)_firm }=\quad \text { the natural logarithm of total assets of the firm } \\
& \mathrm{RO} A_{\text {firm }}=\quad \text { the ratio of earnings before interest and tax divided by total } \\
& \text { assets of the firm } \\
& \text { Debt-to-assets_firm }=\quad \text { the ratio of total liabilities to assets of the firm } \\
& \text { Market-to-book firm }=\quad \text { the market-to-book value of the firm } \\
& \text { Intangibles_firm }=\quad \text { the ratio of intangibles to total assets of the firm } \\
& R \otimes D \_ \text {firm }=\quad \text { the ratio of } R \& D \text { to total assets of the firm } \\
& R \& D \text { dummy_firm }=\quad \text { an indicator variable that equals one if } \mathrm{R} \& \mathrm{D} \text { is not reported } \\
& \text { by the firm and zero otherwise. }
\end{aligned}
$$

Num_of_bus_seg_firm $=\quad$ the number of business segments of the firm

Stock_volatility_firm $=\quad$ the 12-month standard deviation of the stock returns using monthly return data on the firm from CRSP 
Social_capital_firm $=\quad$ the social capital of the county where the firm is headquartered

Alliances_exp_firm $=\quad$ an indicator variable if the firm has prior experience in alliance formation

Number_of_analyst_firm $=\quad$ the number of analysts following the firm

Analyst_Est._Dispersion_firm $=$ the standard deviation of the analysts' estimate of the firm's earnings

Ln(assets)_partner $=\quad$ the natural logarithm of total assets of the partner

$\mathrm{RO} A_{\text {_partner }}=\quad$ the ratio of earnings before interest and tax divided by total assets of the partner

Debt-to-assets_partner $=\quad$ the ratio of total liabilities to assets of the partner

Market-to-book_partner $=\quad$ the market-to-book value of the partner

Intangibles_partner $=\quad$ the ratio of intangibles to total assets of the partner

$R \circledast D \_$partner $=\quad$ the ratio of $R \& D$ to total assets of the partner

$R \& D$ dummy_partner $=\quad$ an indicator variable that equals one if $\mathrm{R} \& \mathrm{D}$ is not reported by the partner and zero otherwise.

Num_of_bus_seg_partner $=\quad$ the number of business segments of the partner

Stock_volatility_partner $=\quad$ the 12-month standard deviation of the stock returns using monthly return data on the partner from CRSP

Social_capital_partner $=\quad$ the social capital of the county where the partner is headquartered in

Alliances_exp_partner $=\quad$ an indicator variable if the partner has prior experience in alliance formation 
Number_of_analyst_partner $=$ the number of analysts following the partner Analyst_Est__Dispersion_partner $=$ the standard deviation of the analysts' estimate of the partner's earnings

Alliance type indicators $=\quad$ eight variables that indicate the type of alliance Industry indicators $=\quad$ indicator variables constructed based on Fama and French's 48 industry grouping

Year indicators $=$ indicator variables based on the year the alliance was announced

We use an OLS test with standard errors clustered by firm and alliance. ${ }^{4}$ The CAR, at least to some extent, is jointly determined; and therefore, the CAR of the two partners from an alliance can be correlated—clustering alliances adjusts for this correlation. The key research variable, Fog partner, and all of the control variables are lagged by one year. For expositional ease, we suppress the subscripts. The control variables we use are quite extensive compared to prior studies that examine the determinants of CAR around an alliance announcement (see for e.g., Chan et al., 1997; Kale et al., 2002). Because measures of linguistic complexity, such as the fog index, in the words of Bushee et al. (2017) "commingle two latent components—obfuscation and information—that are related to information asymmetry in opposite directions", it is important that we control for the informational environment of the firm. We do so by controlling for the size, industry, the number of business segments, the market-to-book value, stock return volatility, the number of analysts and dispersion in the their estimates. Appendix A describes in detail how we construct the variables and the sources of the data.

\footnotetext{
${ }^{4}$ The hypothesis continues to hold when we use alternative clustering. For example, we confirm that the hypothesis is robust when we cluster based on the firm and year of alliance, or by alliance-type and year.
} 
Our method, which controls for the firm's and the partner's characteristics separately, identifies the different effects of the characteristics on the CAR of the firm. An alternative method is to construct the average CAR of the two firms in the alliance (either weighing it equally, or weighing it based on the market values of the firms), and construct control variables in the same way. In contrast to these alternative methods, the advantage of the method we use is that it does not assign an ad hoc weighting to the CAR and allows for greater flexibility on how the firm's and partner's characteristics affect the CAR. To put it differently, in our model it is not the weighted firm's size, or weighted R\&D expenditure, that affects the weighted CAR, rather the CAR of the firm is affected by the size and R\&D expenditure of the firm and the partner separately.

Our method accounts for the fact that an alliance will generate different amounts of wealth for each firm's shareholders that will not be equal or proportional to their market value. Consider Microsoft's alliance with Ivillage Inc. The CAR for Ivillage is affected more because it is a small firm, and the announcement of an alliance with Microsoft might bring recognition to the firm and increase the possibility to partner with other firms — such factors will not affect Microsoft's CAR as it is already a large and well-known firm. Weighing it equally would mean that shareholders' wealth will be equally affected, and weighing it by market value would mean that Microsoft's shareholders' wealth will increase to a greater extent.

Regardless, we verify that the hypothesis continues to hold when we construct one variable per alliance by weighting the CAR and the other variables in the analysis.

\subsection{Measurement of CAR for the firm when a strategic alliance is announced}

If the stock market is rational, then the impact of an economic event should be reflected in the stock prices. If at announcement, a certain type of strategic alliance generates a greater increase in the price of the stock immediately following the announcement, we can say that the market 
perceives that type of strategic alliance as creating a greater amount of wealth for the firm's shareholders.

Because the price of a stock can fluctuate for many reasons, only calculating the changes in price before and after the announcement is imprecise. The research typically uses event studies to extract the changes in the stock prices. The first step in an event study is to select the event window. Because the market often anticipates these events, this anticipation is captured by including the observations well before the event. However, including too many days before or after the event is problematic because the stock prices can be affected by confounding events.

The event window we choose is a five-day window $(-2,+2) .{ }^{5}$ As mentioned in Campbell et al. (1997), this is a popular window (page 151). The next step is to generate the expected returns for the stock. Following Brown and Warner (1985), we use a market model. The CAR is the difference between the return observed in the market and the return expected from the market model. The parameters of the market model are estimated over a 120-day range starting 30 calendar days before the event. For a discussion of the event study method see MacKinlay (1997).

\subsection{Measuring the readability of the partner's $10-\mathrm{K}$ reports}

We use the fog index to measure the readability of the partner's $10-\mathrm{K}$ report. There are other measures of readability, but the fog index is the most popular and a number of studies have used it in recent years (for e.g., Biddle et al., 2009; Dougal et al., 2012; Lehavy et al., 2011; Li, 2008). This index is a linear combination of the average length of the sentences and the occurrence of complex words (words with lengths larger than or equal to three syllables). The value for the index is derived from the following formula:

\footnotetext{
${ }^{5}$ In untabulated tests, we verify that the numerous tests we conduct in our study largely retain their significance when we use a window of $(-1,+1)$.
} 
Fog Index $=0.4 *$ (average number of words per sentence + percentage

of words of three or more syllables)

Envisioned by Robert Gunning, a textbook publisher, this index reflects the number of years of formal education needed to understand the document. The greater the value of the fog index, the harder it is to understand the prose. As explained by Li (2008), a fog index value of 18 means the text is unreadable; 14-18 indicates difficult to read; $12-14$ indicates ideal readability; 10-12 is acceptable; while 8-10 means childish prose. In essence, short sentences written in plain English achieve a better readability score than long sentences written in complicated language.

We recognize that the fog index as a measure of readability is not without problems. The most compelling criticism is articulated by Loughran and McDonald (2014) who argue the fog index has measurement errors because "complex words", one of its key components is misspecified. They note that some of most common complex words in a financial document are easily understood simple words for a finance professional. They recommend using the file size as a proxy for the 10-K. However, recent research shows that the file size also suffers significant measurement errors. Bonsall et al. (2017) note that "a vast amount of the variation in Form10-K file size overtime is driven by the inclusion of content unrelated to the underlying text in the10-K (e.g., HTML, XML, PDFs)" (page 329). An example they present is illustrative. They point out that $99.8 \%$ of file size of Northport Network Systems' 2011 10-K filing was due to 20 pictures in the GIF format.

Because the fog index continues to be a commonly used measure of readability (e.g., Bozanic et al., 2017; Dyer et al., 2017; Lo et al., 2017), we use the fog index as our primary measure of readability because the file size is not clearly a better measure. Regardless, in untabulated results we re-conduct the tests in this study with the file size as the measure for readability and confirm that the results continue to hold. ${ }^{6}$

\footnotetext{
${ }^{6}$ These results are available upon request.
} 
We also use alternative measures of readability: the Kincaid index and Flesch index, to verify that our main results are not sensitive to how we measure readability. Our hypothesis continues to hold.

\section{Data}

Our sample consists of 3,162 firm-years and spans 17 years from 1995 to 2012. This sample comprises data from 1,581 bilateral strategic alliances that occurred among unregulated and nonfinancial U.S. public firms.

Our sample construction is as follows: We first collect data on strategic alliances from SDC Platinum. We require that the alliance is announced between January 1, 1995, and December 31, 2012. We do so because the readability data that we use is available only from 1994 onwards. The sample selection, that we summarize in Panel A of Appendix B, proceeds as follows: We start with 11,056 alliances that occurred between 1995 and 2012. Sequentially, we remove alliances that involve private firms $(7,263)$, are joint ventures (578), belong to the financial or utility industries (90), have multiple partners (113), do not have readability data available (1,009), do not have security price data available (133), or do not have analyst data in IBES (289). We exclude joint ventures because in contrast to a strategic alliance, a joint venture is an equity partnership that involves the creation of a separate legal entity with its own board of directors and managers. However, in a strategic alliance, the partners exert greater control over the day-to-day activities of the alliance. All of the strategic alliances that we include in our study (i.e., licensing agreements, marketing or distribution agreements, research and development agreements, technology transfer agreements, and others) are non-equity partnerships. Because in a joint venture a partner's influence is limited, if any, it is unclear to what extent the readability of a partner's $10-\mathrm{K}$ will affect the CAR around the announcement of a 
joint venture. ${ }^{7}$ We exclude alliances with multiple partners because such an exclusion allows for much cleaner tests on how the partner's characteristics affect the CAR around the announcement. After this filtering, we are left with 1,581 strategic alliances. Because of the construction of our model, the 1,581 alliances lead to 3,162 observations. In order to remove the effects of outliers, we winsorize all of the continuous variables by $0.5 \%$ at both tails.

Appendix B presents more information about our sample. Panel B shows that the number of alliances is high during 1997 to 2000 and low in the last three years of our sample_-2010, 2011 and 2012. Panel $C$ shows that marketing, licensing, R\&D, and technology alliances are among the most common types, which is similar to Chan et al. (1997). These alliances represent about $80 \%$ of the alliances. Panel D shows that almost 56\% of the firms in the sample formed an alliance only once during the sample period. Another 20\% formed two alliances. The rest formed multiple alliances, the highest being Microsoft with 122. Panel E presents the summary statistics for the alliance sample and those in COMPUSTAT. A comparison of the summary statistics shows that our sample has larger firms and more profitable firms, with greater market-to-book ratios'The alliances are common in the following industries: Business services ${ }^{8}$ (34.89\%), Computers (15.02\%), Pharmaceuticals (10.45\%), Electronic Equipment (9.02\%), and Communications (4.51\%). Together, these five industries are about $74 \%$ of the alliances. We provide a detailed breakdown of alliances by industry in a supplemental online appendix.

The summary statistics of our sample are presented in Table 1. The statistics show that the mean CAR is $1.3 \%$ and the standard deviation is $10.8 \%$. The mean of Fog partner is 19.671 and the standard deviation is 1.453 . A fog index of 19.671 indicates that the $10-\mathrm{K}$ reports are quite difficult to read. The statistics also show that about $16 \%$ of the firms do not have R\&D expenditures. By

\footnotetext{
${ }^{7}$ We confirm in untabulated results that even if we were to include them our results continue to hold. Joint ventures are about $5 \%$ of the strategic alliances.

8 This industry includes businesses such as commercial printing, data processing, photofinishing, testing labs, and information retrieval service.
} 
construction, the statistics for the firm and partner controls are very similar but not identical. They are not identical because we have winsorized them, they are identical for the non-winsorized data.

\section{Results}

\subsection{Univariate results}

The univariate results are consistent with our hypothesis: if the partner has a less readable $10-\mathrm{K}$ report, the CAR for the firm around the announcement of the strategic alliance is lower. Figure 3 presents the results graphically. When the fog index of the partner's $10-\mathrm{K}$ report is less than the median, the CAR is $1.81 \%$; when it is more than the median, it is $0.84 \%$. A two-tailed t-test shows that the difference is significant at a $\mathrm{p}$-value of 0.001 . To make sure that our univariate results are not due to how we split the sample, we conduct other univariate tests. We split the sample into three quintiles rather than the median of Fog_partner. A comparison of the mean CAR for the lowest and highest quantiles shows that the difference is greater-for the group with Fog_Partner in the lowest quartile, the average CAR is $2.26 \%$, and for those with a high fog index it is only $0.79 \%$. This difference is statistically significant with a p-value of less than 0.001 . The correlation between $C A R$ $(-2,+2)$ firm and Fog partner is -0.04 and significant with a p-value less than 0.05 . The supplemental online appendix reports the correlations of all the variables we use in our main model.

\subsection{Multivariate results}

\subsubsection{Main result}

The results of the multivariate regression are in line with the univariate results. Ceteris paribus, the greater the fog index of the partner's $10-\mathrm{K}$ report, the lower the CAR from the announcement. 
Panel A of Table 2 displays the results. The p-values are based on standard errors that are clustered by firm and alliance. Column 1 presents the results of the model described in equation 1. The coefficient for Fog partner is -0.0036 and is significant at 5\%. A movement in the partner's fog index from the 25 percentile to the 75 percentile is associated with a decrease in the CAR of -0.0056 $(-0.0036 *(20.418-18.726))$ that is $43 \%$ less than the average increase in the CAR from an announcement $(-0.0056 / 0.013)$. The results are similar when we remove the control variables for the partner's characteristics (Column 2), or when we remove all of the control variables except the year and industry fixed effects (Column 3).

\subsubsection{Main result holds when we use alternative measures of readability}

We use three alternative measures of readability and confirm that the significant association between the readability of the partner's $10-\mathrm{K}$ and the firm's CAR is not sensitive to the way we measure readability. The first alternative measure is the Kincaid index that is calculated as follows: Kincaid $=0.39 *($ total words / total sentences $)+11.8 *($ total syllables / total words $)-15.59$

A higher number in this index represents poor readability. Our results are similar to those of the fog index. The second alternative to the fog index is the Flesch index that is calculated as follows:

Flesch index $=206.835-1.015 *$ (total words / total sentences $)-84.6 *$ (total syllables / total words)

This formula indicates that a bigger number reflects better readability, unlike the fog and the Kincaid indices. Therefore, a positive coefficient for Flesch_partner is consistent with our hypothesis. This is indeed what we find. The third alternative measure is the file size as in Loughran and McDonald (2014). A higher file size indicates poor readability. We find that consistent with our hypothesis, a larger file size for the partner is associated with lower values for the CAR. The results are reported in Panel B of Table 2.

6.2.3. Main result holds when we use a weighted $C A R$ and base our analysis on one observation per alliance 
The hypothesis continues to hold when we construct one variable for each alliance and examine the association between a weighted CAR and a weighted fog index of the two firms in the alliance. Panel $\mathrm{C}$ of Table 2 shows the results. The dependent variable is the average CAR around the announcement of the alliance. The control variables, including the research variable are the weighted average of the two firms. Because each alliance is only one observation, by design we cannot cluster the standard errors by alliance. Rather, we use robust standard errors. In column 1, the variables are weighted averages—-weighted by the market value of the firm. In column 2, the two partners are equally weighted. The coefficient for Fog - value (equally) weighted which is the value (equally) weighted average of Fog partner and Fog firm, is significant at 5\% in both the columns.

\subsubsection{The main result is robust when we use propensity score matching rather than an OLS}

The OLS assumes that the association between the covariates and the dependent variable is linear. If the association between the CAR and Fog_Partner is not linear, then our model arguably is misspecified. To be sure that our results hold, we also use propensity score matching to test our hypothesis. A matching technique such as this one does not assume any sort of relation between the dependent variable and the covariates and is better designed to make sure that the relation is not spurious (Rosenbaum and Rubin, 1983).

The main result is robust when we use the propensity score matching. Panel D of Table 2 contains the results. The steps for conducting the matching are as follows: We first divide the sample into two groups based on the median level of Fog partner. The observations where the partner has a higher fog index are considered the treated group and those with a lower fog index the control group. For each of the observations in the treated and control groups, we calculate the propensity score - the probability of belonging to the group with high Fog partner. We use the following control variables and a logit model in constructing the propensity score: Ln(assets)_firm, ROA_firm, Debt-to-Assets_firm, Market-to-Book_firm, Intangibles_firm, R\&D_firm, R\&D Dummy_firm, 
Number_of_bus_seg_firm, Stock_volatility_firm, Social_capital_firm, Alliance_exp_firm, Number_of_analyst, Analyst_Est._Dispersion, Industry indicators, and Year indicators. We use all possible firm-level control variables from our regression (summarized in equation 1) in constructing a match. Then for each observation from the treated group, we find the nearest neighbor from the control group and construct a matched group. We choose those with the smallest difference in their propensity score in terms of the absolute value and match them with a replacement. In a graph we do not present in the paper for brevity we examine whether the propensity scores of the two groups are similar-we find they are- thus the match is good. We then conduct a two-tailed t-test between the treated sample and the matched sample.

The results of the analysis show that the mean of CAR $(-2,+2) \_$firm is 0.005 for the treated group and three and half times higher, 0.019 , for the matched group. The difference is significant at a p-value of less than 0.001 . The matched sample is similar to the treated sample in terms of the other variables - there is no statistically significant difference between the means of the variables we match. We report these results in Panel D of Table 2.

\subsection{Difference-in-difference estimation using the plain English language rule of 1998}

In October of 1998, the SEC implemented its Plain English Initiative (PEI). The PEI improved the readability of $10-\mathrm{Ks}$; this makes it possible to conduct a difference-in-difference analysis. The key idea behind our analysis is that PEI's effect on 10-K readability was particularly strong for firms that had less readable 10-Ks before the act, and weaker for firms that already had more readable 10-Ks before the act.

If readability of a partner's $10-\mathrm{K}$ indeed has an effect on investors' reaction, as we argue, then this notion implies that before the PEI, the investors' reaction to the announcement of an alliance with a firm with a less readable 10-K will be significantly lower compared to an alliance with a firm with a more readable 10-K. More importantly, this difference will narrow considerably after 
PEI, presumably because the readability of firm with poor readability will improve dramatically after PEI.

We design a test for this concept. Thus, we use only two years of data: 1997, the year before, and 1999 the year after the PEI. ${ }^{9}$ We note here that in an ideal situation we would want to track the same two firms that form an alliance before and after PEI. However, it is very unlikely that the same two firms form one a year before and another the year after the PEI. Therefore, we cannot conduct such tests. In our set up, a firm forms an alliance with different firms in 1997 and in 1999. In other words, we keep one of the partners in the alliance the same for both years.

We follow the steps discussed in Hwang and Kim (2017). As in their study, we divide the firms into quartiles (4 groups) based on the readability of their 10-Ks in 1997 . We consider the group with the least readable annual report the treatment group. Next, for each observation in the treatment group, we find a match from the most readable group. We do a Mahalanobis-metric match. We match based on all the firm-level characteristics we control for in our main model: ROA_firm, Debt-to-Assets_firm, Market-to-Book_firm, Intangibles_firm, R\&D_firm, R\&D Dummy_firm, Number_of_bus_segment_firm, Stock_volatility_firm, Social_capital_firm, Allianc_exp_firm, Number_of_analyst_firm, Analyst_Est._Dispersion_firm. We consider this group the control group.

For each treatment and control group observation, we compare the annual reports of 1997 and 1999. As expected we find that the readability of the treatment group improved dramatically between 1997 and 1999. This was not the case for the control group. ${ }^{10}$ Next, we estimate the following regression.

\footnotetext{
${ }^{9}$ The effect of PEI is likely to be stronger immediately after PEI and might wane in later years. ${ }^{10}$ The average fog index of the treatment group is 21.30 for 1997 and 20.01 for 1999 . The difference was significant at five percent. The average fog index for the control group is 17.83 for 1997 and 18.10 for 1999, and the difference was not significant.
} 


$$
\text { CAR }(-2,+2) \_ \text {firm }=\beta_{0}+\beta_{1} \text { TreatGroup* Year } 1999+\text { TreatGroup }+ \text { Year } 1999+X+e
$$

Where,

TreatGroup $=$ one if the partner that belongs to the group in the lowest quartile of readability in 1997, and zero otherwise. By construction, those coded as zero belong to the control group that has readability in the highest quartile (in 1997.

Year1999 $=$ one if the alliance took place in 1999, and zero otherwise. By construction, the zero is for firms that formed an alliance in 1997.

$X=\quad$ the set of control variables we use in our main model.

The results are reported in Panel E of Table 2. The coefficient for TreatGroup is negative and TreatGroup* Year 1999 is positive. They are both significant at five percent. This significance indicates that in the pre-PEI period (1997), partnering with a firm that belongs in TreatGroup results in a significantly lower abnormal stock return, but this difference narrows significantly in the postPEI period (1999). In other words, our difference-in-difference analysis indicates that firms that had less readable annual reports in 1997 have significantly better written annual reports in 1999. And presumably because of this change, the difference in the CAR of a firm that formed an alliance with a firm that had less readable annual report and one that had a more readable annual report has narrowed significantly.

6.4. The effect of the readability of a partner's $10-K$ on a firm's $C A R$ is stronger when the partner's 10-K is downloaded to a greater extent

As we discuss in the introduction, there is an increased interest in reading the $10-\mathrm{Ks}$ when an alliance is announced. ${ }^{11}$ We ask if the association between the readability of a partner's $10-\mathrm{K}$ and the CAR around an alliance's announcement is stronger in instances where the partner's $10-\mathrm{K}$ is

\footnotetext{
${ }^{11}$ As in Drake et al. [2016] we collect data on the number of downloads of 10-Ks from the SEC website. The website we
} collect data from is https://www.sec.gov/data/edgar-log-file-data-set.html 
downloaded to a greater extent. To do so, we construct an indicator variable, High downloads_partner, based on the number of downloads of a firm's $10-\mathrm{K}$ from the SEC website. If the partner's $10-\mathrm{K}$ is downloaded more than the median number of alliance on the day after the alliance is announced, then we code High downloads_partner as one, and zero otherwise. We then interact this variable with Fog_partner. Next, we introduce High downloads_partner and Fog_partner*High downloads_partner in the main regression model used to examine the association between $C A R(-2,+2)$ firm and Fog_partner. Consistent with the idea that the effect of the readability of a partner's $10-\mathrm{K}$ is stronger when the partner's $10-\mathrm{K}$ is downloaded more aggressively, we find that the interaction term Fog_partner*High downloads_partner is negative and significant at less than 1 percent. They are reported in columns, 1, 2, and 3 of Panel F of Table 2.

We mitigate the concern that the significance of the interaction term is because we constructed an indicator variable based on the number of downloads by also interacting two continuous variables. The interaction term Fog partner*Downloads_partner is constructed by multiplying the fog index of the partner and the number of times the partner's $10-\mathrm{K}$ was downloaded from the SEC website on the day after the alliance was announced. The results reported in columns 4, 5, and 6 of Panel F of Table 2, show that Fog_partner*Downloads_partner is negative and significant.

\section{Additional tests}

To gain a better understanding of the relation between the readability of the partner's $10-\mathrm{K}$ report and the firm's CAR after announcing a strategic alliance, we perform additional tests.

\subsection{Moderation tests}


We investigate whether the readability might affect the CAR more strongly in certain situations where the information asymmetry is greater. The idea is that the effect of the investors' confidence or lack thereof because of the readability will be stronger where there is already, as investors suspect, greater information asymmetry. The three tests we conduct have results largely consistent with this idea.

\subsubsection{The effect of readability on the $C A R$ is stronger in industries where the firm does less due diligence before} forming an alliance compared to one where due diligence is extensive

We know that due diligence before forming an alliance varies considerably-there is less in the high-tech industry and more in the pharmaceutical industry (Nevin, 2014). If low credibility is due to a less readable $10-\mathrm{K}$, the effect will likely be greater for a firm from a high-tech industry as investors believe managers are less diligent in pursuing their alliance. In contrast, investors will worry less about an alliance in the pharmaceutical industry because they presume greater due diligence.

To test this concept, we limit our sample to only those firms that belong to either the pharmaceutical or the high-tech industry. Like Nevin [2014], by high-tech we mean software and hardware. In Fama-French's 48 industry classifications, Computer refers only to the hardware. We define a firm to be high-tech if it is also classified as belonging to software related industries based on the four digit SIC.

We run regressions for these two groups separately and test if the coefficient for Fog_partner differs when using a stacked F-test. We also construct an interaction term for Fog_Partner and Hightech where an indicator variable equals one if the firm belongs to the High-tech industry. We also conduct a pooled regression. 
For both of these tests, our results indicate that the effect of the readability of the partner's $10-\mathrm{K}$ on the firm's CAR is stronger when the firm belongs to the high-tech industry. The results are reported in Panel A of Table 3.

\subsubsection{The effect of the readability of a partner's $10-K$ report is stronger when the alliance is with a partner from a different industry}

When a firm forms an alliance with a partner in the same industry, the difficulty in understanding the partner's $10-\mathrm{K}$ and the ensuing lack of credibility should matter less, because investors can assume the firm partially compensates for poor readability because it better understands the environment in which its partner operates. But when the alliance is with a partner from a different industry, it is difficult to do so. This line of logic suggests that when an alliance is with a partner from a different industry, the readability of the partner's $10-\mathrm{K}$ should matter more.

Our results support this logic. We use the Fama-French's 48 industry classification to split the sample into alliances that occur between firms in the same industry and those that occur between different industries. We find that the effect of Fog_partner on CAR (-2,+2)_firm is a lot stronger when the alliances involve firms from different industries. We report the results in Panel B of Table 3. The coefficient for Fog partner is -0.0045 and is significant at $5 \%$ when the alliance is with a partner from a separate industry (Column 1) and -0.0053 and non-significant when it is within the same industry (Column 2). We caution the reader that the difference in statistical significance may simply be due to the sample size. An F-test shows that the difference is statistically significant with a p-value less than 0.049 .

We also conduct a pooled test where we interact Fog_partner and Same Inds.—a variable that equals one when the two partners are from a different industry and zero otherwise. The coefficient 
sign is positive and not statistically significant (Column 3). As such, we caution readers to interpret these results as only suggestive and not conclusive.

\subsubsection{The effect of the readability of the partner's 10-K report is stronger for alliances formed before 2002}

If the poor readability of the partner's $10-\mathrm{K}$ adversely affects the CAR because they are perceived as less credible, then the effect of poor readability should be much stronger before the Sarbanes Oxley Act (SOX) of 2002. The SOX brought into effect numerous changes to financial reporting. These changes were made to increase the credibility of $10-\mathrm{K}$ reports. Section 302 , considered one of the most important provisions of SOX, asks key managers to certify financial statements. This certification means that these managers: (i) have to read the financial statement, (ii) not be aware of any false or misleading statements (or key omitted discourse), and (iii) that the management considers it to present an accurate picture of the firm's financial condition (Louwers et al., 2013). In the pre-SOX period, the credibility that the management exudes should play a stronger role.

Our results in Panel C of Table 3 confirm such to be the case. The effect of the partner's readability in the pre-SOX period is stronger. To test this, we split the sample into the pre-SOX period and the post-SOX period. The pre-SOX period consists of the following years: 2000, 2001 and 2002; and the post-SOX consist of observations after 2003, 2004 and 2005. The coefficient for Fog_Partner in the pre-SOX period is -0.0086 with a p-value of 0.029 (Column 1 ) and in the postSOX period is nonsignificant (Column 2). The difference is statistically significant at a p-value less than 0.0321 .

We also conduct a pooled test, where we interact Fog _partner and Pre-SOX_a variable that equals one if the alliance was formed before SOX and zero otherwise. We find that the coefficient for Fog _partner * Pre-SOX is negative and statistically significant (Column 3) at 5\%. 


\subsection{The alliance with a partner with less readable $10-K$ is unlikely to be executed}

We argue investors have less confidence in an alliance with partners that have less readable 10-Ks. Therefore, the investors will estimate a reduced NPV for the potential alliance, and hence a reduced CAR. We argue that there is a behavioral explanation for this phenomenon based on the prospect theory. But as we point out in the introduction, the explanation need not be exclusively behavioral, there could be a rational side to the investors' reaction. Are investors rational in having less confidence in an alliance with a firm that has a less readable 10-K?

Evidence that this type of partnership indeed has a high chance of failure supports the idea that investors are also being rational. We recognize it is hard to measure the success of an alliance as it can depend on the expectations. As such, it is a difficult test to conduct-especially using a large sample. We pursue the best possible option available to us. The SDC Platinum database has data on announced strategic alliances that were terminated before being realized. These data provide some idea on the risk of an alliance failing. We collect these data and construct an indicator variable Withdrawn that equals one if the deal announced does not occur and zero otherwise. ${ }^{12}$ Because the dependent variable is an indicator variable, we use a logit model to examine the probability of a deal failing.

In line with our argument, we find that the readability of the partner's $10-\mathrm{K}$ report is associated with an increased likelihood of a withdrawal. We report these results in Table 4. To be consistent, we use the same control variables as we do to examine the $C A R(-2,+2)$ firm, and cluster the standard errors by alliance type and firm. ${ }^{13}$ We find that the coefficient for Fog_Partner is positive and significant at 1\% (Column 1). Based on the results reported in Column 1, a one standard deviation increase in Fog_Partner is associated with $9 \%$ greater odds of withdrawal (exp

\footnotetext{
12 The mean of this variable is 0.28 , which means that on average about $28 \%$ of the strategic alliances are withdrawn even before they start.

13 The results hold at a higher significance level if we do not control for firm's or the partner's characteristics.
} 
$(0.0599 * 1.453))$. Even if we control for $C A R(-2,+2)$ firm and $C A R(-2,+2) \_$partner, we continue to find that readability is associated with greater probability that the alliance will be withdrawn before realization, albeit at a lower significance level (Column 2). ${ }^{14}$ Arguably, given that we do not observe who is initiating the withdrawal, using the average of Fog_Partner and Fog_firm might be much more appropriate. We find that the results are largely similar (Columns 3, 4). Overall, these results show that if the market perceives that a partnership with a firm that uses long sentences and complex words brings less wealth to the firm's shareholders, they are probably right. ${ }^{15}$

\section{Discussion on the main result}

In this section, we rule out a couple of alternative explanations for our results. We also address some of the questions that might arise.

\subsection{Opacity due to readability adversely affects strategic alliances but the opacity due to earnings management does not}

Our focus is on the readability of the $10-\mathrm{K}$ report. We focus on this aspect rather than earnings management because the earnings of the partner are not a major factor the firm is looking at when seeking a strategic alliance. In fact, our analysis shows that the profitability of the partner does not matter when predicting the CAR of the firm. The coefficient for ROA_partner is nonsignificant with a p-value of 0.311 (see Table 2, Panel A, Column 1).

Still, an argument can be made that although the profitability of the past year does not matter, the opacity due to earnings management might make investors wary about the partner's credibility, and therefore the partner's earnings management might affect the CAR. However, we do not find such to be the case-the opacity due to earnings management does not seem to matter. We reach this conclusion based on the following analysis: We calculate the discretionary accruals based

\footnotetext{
${ }^{14}$ We do not control for $C A R(-2,+2)$ firm or $C A R(-2,+2)$ partner in these regressions because CAR will control for all market related factors, including the effect of readability, which is associated with the CAR.

${ }^{15}$ In unreported test, we find that the effect of Fog partner on Withdrawal is stronger when the alliance is between firms from different industries.
} 
on the modified Jones model (Jones, 1991; Klein, 2002). ${ }^{16}$ Using this variable, we construct EM_Jones3_partner, which is the average of the absolute value of the discretionary accruals in the past three years for the partner. ${ }^{17}$ When we replace Fog _partner with EM_Jones3_partner, EM_Jones3_partner is not significant—the p-value is 0.119 (Table 5, Panel A, Column 1). Further, when we include both Fog _partner and EM_Jones3_partner, Fog _partner retains its significance at 5\%, despite Fog_partner and EM_Jones3_partner being positively correlated.

These additional findings that the opacity of the earnings is nonsignificant strengthens our argument that the opacity due to poor fluency drives our results.

\subsection{The omission of corporate governance variables does not drive the results}

In our model, we do not control for corporate governance because it halves the sample size. One could argue the omission of these variables might be driving our main result because the poor governance might have correlations with how a partner writes its annual report as well as with the market's perception of the partner. To make sure that this is not the case, we re-test our hypothesis by controlling for the percentage of independent directors, and the number of number of directors for the partner and the firm. In addition, we also control for the aggregate measures of corporate governance characteristics of the partner and the firm. First, we use the G-index constructed by Gompers et al. (2003) that uses 28 governance characteristics. The higher the value of this index, the lower the corporate governance's quality is. As is common in the research that uses the G-index, we replace the missing values by using the previous year's values. We also repeat the same analysis, but this time use the E-index first constructed by Bebchuk et al. (2009), who argue that only using the six key governance provisions in the construction of the G-index is a much better measure. Our

\footnotetext{
${ }^{16}$ When we use alternative methods to measure earnings management such as performance-adjusted discretionary accruals as suggested as in Kothari et al. (2005) or Francis et al. (2005) the results remain the same. The earnings management of the partner does not affect the CAR. For brevity we do not report the results in the paper.

${ }_{17}$ The results are the same when we use only the average of the past two years instead of the past three years.
} 
results remain robust when we control for these corporate governance measures. Panel B of Table 5 reports the results.

\subsection{The results are robust when we control for managerial ability}

Arguably, the skills of the top management, the CEO in particular, might affect how they write their 10-Ks. When a firm with an unskilled CEO partners with another firm that has an unskilled CEO, the stock market's reaction to the alliance might be subdued. This reaction is partly because their $10-\mathrm{K}$ is opaque and partly because the market does not have a high opinion of the managers. Put differently, arguably, the omission of managerial ability might affect out results.

We verify that the results are robust when we control for this possibility. Thus, we control for the firm's managerial ability with data from Demerjian et al. (2012). ${ }^{18}$ In addition, we also control for the industry adjusted return on assets and CEO fixed effect. We continue to find that when the readability of the partner's $10-\mathrm{K}$ is poor, the stock market's reaction to the firm's announcement of a strategic alliance is lower. The results are reported in Panel C of Table 5.

8.4. CAR around announcement of an alliance is associated with and is an indicator of whether the alliance gets withdrawn before being realized

We argue that when the readability of a partner's $10-\mathrm{K}$ report is poor, then investors suspect a high chance of failure and embed such suspicion in the price of the stock. This argument, as we mention earlier, is consistent with the literature (e.g.,Gulati et al., 2009; Kale et al., 2002).

We test if this concept holds in our data and with our measure of failure. To do so, we test if an alliance that eventually gets withdrawn before realization tends to have a lower CAR around the announcement date. If it does, then the lower CAR means that investors can predict, at least to some extent, the likelihood of an alliance failure. Panels A and B of Table 7 compare the CAR (-

\footnotetext{
${ }^{18}$ This data is available at http://faculty.washington.edu/pdemerj/data.html. We thank the authors for making the data publicly available.
} 
2,+2)_alliance equally weighted and CAR (-2,+2)_alliance value weighted respectively. Regardless of whether we test the equality of means on the medians, for both these measures we find that for an alliance where Withdrawn equals one, the CAR around the announcement has a lower mean and median. The results are reported in Table 6.

\subsection{Why do firms enter into alliance with firms with less readable annual report?}

Our study shows the firm's CAR around the announcement is lower when the partner has a less readable annual report. However, why do firms form alliances with partners with less readable annual reports in the first place? To answer this question succinctly, we note that firms form an alliance for many reasons. But as long as the expected NPV is positive, it can be optimal to form an alliance with a firm that has a less readable annual report. Further, the univariate results in Figure 3 show that even when the readability of the partner is in the bottom $33 \%$, the $C A R(-2,+2)$ firm is still positive.

\section{6. Does readability of corporate press releases announcing the strategic alliance matter?}

Our study raises a related question: Does the readability corporate press releases announcing the alliance have any effect on the CAR around announcement? Though not required by law firms often announce their strategic alliance in press releases. Arguably, the first impression after reading the announcement might affect the view of investors - a less readable announcement might make the investors pessimistic about the strategic alliance. In contrast, if the investors do not find sufficient information in the announcement and use the announcement simply as a trigger to read the $10-K s$, then the readability of the announcement might not have a salient effect on the CAR.

To examine this question, we collect data on corporate press releases of the strategic alliances in our sample and calculate their fog index. ${ }^{19}$ We label this variable Fog_press_release. Because

\footnotetext{
${ }^{19}$ We use the https://readability-score.com/ to calculate the fog indexes of the announcement.
} 
not all firm's announcements come out with corporate press releases of the alliance, our sample size for these tests is smaller. Our sample is reduced by almost 43\% to 1,068 alliances from 1,870 alliances. ${ }^{20}$ Because the announcement applies to both firms, we run a regression that uses the weighted CARs of both firms.

Regardless of whether we use equally weighted or value weighted, we do not find a significant association between $C A R(-2,+2)$ firm and Fog_press_release either in the univariate or multivariate analyses. For brevity, we do not report the univariate results. Panels A and B of Table 7 show the multivariate results. This is not surprising as investors do not get sufficient information to assess how much wealth the alliance will bring to shareholders from the announcement because announcements are short, less readable than the $10-\mathrm{Ks}$, and often follow a boilerplate template. An example of a corporate press release regarding the announcement of an alliance is presented in the supplemental online appendix.

\section{7. Do differences and match between the partners in an alliance matter?}

Two more related question arise: Does the absolute value of the difference in the $10-\mathrm{K}$ readability between the partner and the firm affect investors' perception? Does the relative size of the two partners moderate the effect of the partner's $10-\mathrm{K}$ readability on a firm's CAR. The answer to both these questions are negative. When we construct a new variable that takes the absolute value of the difference in the readability of the $10-\mathrm{K}$ and introduce it in our main model, the variable is not significant. And, when we construct an indicator variable that equals one if the firm is larger than its partner and zero otherwise and interact it with Fog _partner, we do not find that the interaction is significant at 10 percent. For brevity, we do not report these results in the paper.

\section{Additional Robustness Tests of the Main Result}

\footnotetext{
20 The SDC uses data from articles authored by journalists from the popular press, not just corporate press releases. Therefore, our sample size when examining the effect of the readability of a partner's 10-K on a firm's CAR around announcements are larger.
} 
For brevity, we do not tabulate the results from additional robustness tests. The tables are instead available in the online appendix. However, we discuss the results in this section.

\subsection{Our main result is valid for recent years and will likely be in the future}

Because we do not find that the readability of a partner's annual report affects the CAR of an alliance after in the next two years after 2002, this raises concerns on whether readability matters anymore.

Yet, despite the law, managers find ways to get around the rules (Kane, 1981), and the investor's belief in the effectiveness of a certain regulation can wane. The effectiveness of SOX should wane after some years, and investors will no longer perceive SOX as guaranteeing credibility to the extent that they do not care about the readability of annual reports.

If our argument is true, then by excluding the years right after SOX and using the later years in our sample period, we should find that readability still affects the perception of an alliance's success. To test this idea, we limit the sample to only the years from 2010 to 2012 and re-test our hypothesis. We also re-test limiting our sample from 2007 to 2012. In both cases, consistent with our argument, we find that the readability negatively affects the perception of the alliance's success

\subsection{The main result is robust when we use the partner's readability over the last three years, rather than the past year}

There is the possibility that the investors are concerned not only about the readability of the 10-K reports from a year before the strategic alliance but also their readability over the past two or three years. Thus, we reproduce our main result from Table 2 but this time instead of Fog_partner, we use Fog_partner (Average of last 3 years). The main results hardly change. 


\subsection{The main result is robust when we use alternative windows for $C A R$}

To make sure that our results are not dependent on our window, we verify that the results are similar when we use a smaller window of $(-1,+1)$ or a bigger window of $(-1,+14)$.

\section{Conclusion}

How a firm writes its annual report affects investors' perceptions. Recent research shows that firms that have less readable annual reports trade at a discount and have a higher cost of debt. In this study, we ask if a firm's association with another firm that has a less readable annual report can also affect investors' perceptions. We use a strategic alliance as a setting to investigate this issue. We examine if the firm's CAR around the announcement of a strategic alliance is dependent on the readability of a partner's $10-\mathrm{K}$ report. We find that alliances with partners who have poorly written 10-K reports create less optimism—and the CAR is lower. The effect is nontrivial and robust.

Our study contributes to a new stream in the finance literature that argues it pays to write well (Ertugrul et al., 2017; Hwang and Kim, 2017). Our study shows that not only does it pay to write well, but it also pays well to form alliances with a firm that writes well.

\section{REFERENCES}

Alter, A.L., Oppenheimer, D.M., 2006. Predicting Short-Term Stock Fluctuations by Using Processing Fluency. Proceedings of the National Academy of Sciences of the United States of America 103, 9369-9372.

Amici, A., Fiordelisi, F., Masala, F., Ricci, O., Sist, F., 2013. Value creation in banking through strategic alliances and joint ventures. Journal of banking \& finance 37, 1386-1396.

Anand, B.N., Khanna, T., 2000. Do firms learn to create value? The case of alliances. Strategic management journal 21, 295-315.

Arino, A., De La Torre, J., 1998. Learning from failure: Towards an evolutionary model of collaborative ventures. Organization science 9, 306-325.

Bamford, J., Gomes-Casseres, B., Robinson, M., 2004. Envisioning collaboration: Mastering alliance strategies. San Francisco: Jossey-Bass.

Bebchuk, L., Cohen, A., Ferrell, A., 2009. What matters in corporate governance? Review of Financial Studies 22, 783-827.

Biddle, G.C., Hilary, G., Verdi, R.S., 2009. How does financial reporting quality relate to investment efficiency? Journal of accounting and economics 48, 112-131.

Blinder, A.S., Ehrmann, M., Fratzscher, M., De Haan, J., Jansen, D.-J., 2008. Central bank communication and monetary policy: A survey of theory and evidence. National Bureau of Economic Research. 
Bonsall, S.B., Leone, A.J., Miller, B.P., Rennekamp, K., 2017. A plain English measure of financial reporting readability. Journal of accounting and economics 63, 329-357.

Bonsall, S.B., Miller, B.P., 2016. The impact of narrative disclosure readability on bond ratings and the cost of debt capital. Review of Accounting Studies forthcoming.

Boone, A.L., Ivanov, V.I., 2012. Bankruptcy spillover effects on strategic alliance partners. Journal of Financial Economics 103, 551-569.

Bozanic, Z., Hoopes, J.L., Thornock, J.R., Williams, B.M., 2017. IRS attention. Journal of Accounting Research 55, 79-114.

Brown, S.J., Warner, J.B., 1985. Using daily stock returns: The case of event studies. Journal of Financial Economics 14, 3-31.

Bushee, B.J., Gow, I.D., Taylor, D.J., 2017. Linguistic Complexity in Firm Disclosures: Obfuscation or Information? . Journal of Accounting Research 56, 85-121.

Campbell, J.Y., Lo, A.W.-C., MacKinlay, A.C., 1997. The econometrics of financial markets. princeton University press Princeton, NJ.

Chan, S.H., Kensinger, J.W., Keown, A.J., Martin, J.D., 1997. Do strategic alliances create value? Journal of Financial Economics 46, 199-221.

Chiou, I., White, L.J., 2005. Measuring the value of strategic alliances in the wake of a financial implosion: Evidence from Japan's financial services sector. Journal of banking \& finance 29, 2455-2473.

Chou, T.-K., Ou, C.-S., Tsai, S.-H., 2014. Value of strategic alliances: Evidence from the bond market. Journal of banking \& finance 42, 42-59.

Cohen, L., Frazzini, A., Malloy, C., 2008. The small world of investing: Board connections and mutual fund returns. Journal of Political Economy 116, 951-979.

Das, T.K., Teng, B.-S., 2001. Trust, control, and risk in strategic alliances: An integrated framework. Organization studies 22, 251-283.

Deeds, D.L., Hill, C.W., 1996. Strategic alliances and the rate of new product development: an empirical study of entrepreneurial biotechnology firms. Journal of Business Venturing 11, 41-55.

Demerjian, P., Lev, B., McVay, S., 2012. Quantifying managerial ability: A new measure and validity tests. Management Science 58, 1229-1248.

Dougal, C., Engelberg, J., Garcia, D., Parsons, C.A., 2012. Journalists and the stock market. Review of Financial Studies, hhr133.

Dyer, J.H., Singh, H., 1998. The relational view: Cooperative strategy and sources of interorganizational competitive advantage. Academy of management review 23, 660-679.

Dyer, T., Lang, M., Stice-Lawrence, L., 2017. The evolution of 10-K textual disclosure: Evidence from Latent Dirichlet Allocation. Journal of accounting and economics 64, 221-245.

Engelberg, J., Gao, P., Parsons, C.A., 2012. Friends with money. Journal of Financial Economics 103, 169188.

Ernst, D., 2004. Envisioning collaboration. Mastering alliance strategies. San Francisco: Jossey-Bass.

Ertugrul, M., Lei, J., Qiu, J., Wan, C., 2017. Annual report readability, tone ambiguity, and the cost of borrowing. Journal of Financial and quantitative Analysis 52, 811-836.

Fernandez-Duque, D., Baird, J.A., Posner, M.I., 2000. Executive attention and metacognitive regulation. Consciousness and cognition 9, 288-307.

Francis, J., LaFond, R., Olsson, P., Schipper, K., 2005. The market pricing of accruals quality. Journal of accounting and economics 39, 295-327.

Friberg, R., Seiler, T., 2017. Risk and Ambiguity in 10-Ks: An Examination of Cash Holding and Derivatives Use. Journal of Corporate Finance.

Gomes-Casseres, B., Hagedoorn, J., Jaffe, A.B., 2006. Do alliances promote knowledge flows? Journal of Financial Economics 80, 5-33.

Gompers, P., Ishii, J., Metrick, A., 2003. Corporate governance and equity prices. Quarterly Journal of Economics 118, 107-155.

Guiso, L., Monte, F., Sapienza, P., Zingales, L., 2008. Diversity - Culture, gender, and math. Science 320, 1164-1165. 
Guiso, L., Sapienza, P., Zingales, L., 2004. The role of social capital in financial development. American Economic Review 94, 526-556.

Gulati, R., Lavie, D., Singh, H., 2009. The nature of partnering experience and the gains from alliances. Strategic management journal 30, 1213-1233.

Hoberg, G., Lewis, C., 2017. Do fraudulent firms produce abnormal disclosure? Journal of Corporate Finance 43, 58-85.

Hribar, P., Collins, D.W., 2002. Errors in estimating accruals: Implications for empirical research. Journal of Accounting Research 40, 105-134.

Hwang, B.-H., Kim, H.H., 2017. It pays to write well. Journal of Financial Economics 124, 373-394.

Jansen, D.-J., 2011. Does The Clarity Of Central Bank Communication Affect Volatility In Financial Markets? Evidence From Humphrey-Hawkins Testimonies. Contemporary Economic Policy 29, 494-509.

Jones, J.J., 1991. Earnings Management during Import Relief Investigations. Journal of Accounting Research 29, 193-228.

Kale, P., Dyer, J., Singh, H., 2001. Value creation and success in strategic alliances:: alliancing skills and the role of alliance structure and systems. European Management Journal 19, 463-471.

Kale, P., Dyer, J.H., Singh, H., 2002. Alliance capability, stock market response, and long-term alliance success: the role of the alliance function. Strategic management journal 23, 747-767.

Kale, P., Singh, H., Bell, J., 2009. Relating well: Building capabilities for sustaining alliance networks. The network challenge: Strategy, profit, and risk in an interlinked world, 343-356.

Kane, E.J., 1981. Accelerating inflation, technological innovation, and the decreasing effectiveness of banking regulation. The Journal of Finance 36, 355-367.

Kang, N.-H., Sakai, K., 2001. New patterns of industrial globalisation: cross-border mergers and acquisitions and strategic alliances. OECD.

Klein, A., 2002. Audit committee, board of director characteristics, and earnings management. Journal of accounting and economics 33, 375-400.

Kothari, S.P., Leone, A.J., Wasley, C.E., 2005. Performance matched discretionary accrual measures. Journal of accounting and economics 39, 163-197.

Laksmana, I., Tietz, W., Yang, Y.-W., 2012. Compensation discussion and analysis (CD\&A): Readability and management obfuscation. Journal of Accounting and Public Policy 31, 185-203.

Lane, R.D., Reiman, E.M., Axelrod, B., Yun, L.-S., Holmes, A., Schwartz, G.E., 1998. Neural correlates of levels of emotional awareness: Evidence of an interaction between emotion and attention in the anterior cingulate cortex. Journal of Cognitive Neuroscience 10, 525-535.

Lawrence, A., 2013. Individual investors and financial disclosure. Journal of accounting and economics 56, 130-147.

LeDoux, J., 1998. The emotional brain: The mysterious underpinnings of emotional life. Simon and Schuster.

Lee, Y.J., 2012. The Effect of Quarterly Report Readability on Information Efficiency of Stock Prices*. Contemporary Accounting Research.

Lehavy, R., Li, F., Merkley, K., 2011. The effect of annual report readability on analyst following and the properties of their earnings forecasts. The Accounting Review 86, 1087-1115.

Lev-Ari, S., Keysar, B., 2010. Why don't we believe non-native speakers? The influence of accent on credibility. Journal of Experimental Social Psychology 46, 1093-1096.

Li, F., 2008. Annual report readability, current earnings, and earnings persistence. Journal of accounting and economics 45, 221-247.

Lo, K., Ramos, F., Rogo, R., 2017. Earnings management and annual report readability. Journal of accounting and economics $63,1-25$.

Loughran, T., McDonald, B., 2014. Measuring readability in financial disclosures. The Journal of Finance.

Louwers, T.J., Ramsay, R.J., Sinason, D.H., Strawser, J.R., Thibodeau, J.C., 2013. Auditing \& assurance services, Sixth ed. McGraw-Hill New York, NY.

Lundholm, R.J., Rogo, R., Zhang, J.L., 2014. Restoring the tower of Babel: How foreign firms communicate with US investors. The Accounting Review 89, 1453-1485. 
Lunnan, R., Haugland, S.A., 2008. Predicting and measuring alliance performance: A multidimensional analysis. Strategic management journal 29, 545-556.

MacKinlay, A.C., 1997. Event studies in economics and finance. Journal of economic literature, 13-39.

Miller, B.P., 2010. The effects of reporting complexity on small and large investor trading. The Accounting Review 85, 2107-2143.

Moffitt, K., Burns, M.B., 2009. What does that mean? Investigating obfuscation and readability cues as indicators of deception in fraudulent financial reports. AMCIS 2009 Proceedings, 399.

Nevin, M.M., 2014. The Strategic Alliance Handbook: A Practitioners Guide to Business-to-business Collaborations. Ashgate Publishing, Ltd.

Oppenheimer, D.M., 2006. Consequences of erudite vernacular utilized irrespective of necessity: Problems with using long words needlessly. Applied Cognitive Psychology 20, 139-156.

Ozmel, U., Robinson, D.T., Stuart, T.E., 2013. Strategic alliances, venture capital, and exit decisions in early stage high-tech firms. Journal of Financial Economics 107, 655-670.

Price, S.M., Doran, J.S., Peterson, D.R., Bliss, B.A., 2012. Earnings conference calls and stock returns: The incremental informativeness of textual tone. Journal of banking \& finance 36, 992-1011.

Reber, R., Schwarz, N., Winkielman, P., 2004. Processing fluency and aesthetic pleasure: Is beauty in the perceiver's processing experience? Personality and social psychology review 8, 364-382.

Rennekamp, K., 2012. Processing fluency and investors' reactions to disclosure readability. Journal of Accounting Research 50, 1319-1354.

Robinson, D.T., 2008. Strategic Alliances and the Boundaries of the Firm. Review of Financial Studies 21, 649-681.

Rosenbaum, P.R., Rubin, D.B., 1983. The central role of the propensity score in observational studies for causal effects. Biometrika 70, 41-55.

Rupasingha, A., Goetz, S.J., Freshwater, D., 2006. The production of social capital in US counties. The Journal of Socio-Economics 35, 83-101.

Shah, A.K., Oppenheimer, D.M., 2007. Easy does it: The role of fluency in cue weighting. Judgment and Decision Making 2, 371-379.

Tetlock, P.C., 2007. Giving content to investor sentiment: The role of media in the stock market. The Journal of Finance 62, 1139-1168.

Tetlock, P.C., Saar-Tsechansky, M., Macskassy, S., 2008. More than words: Quantifying language to measure firms' fundamentals. The Journal of Finance 63, 1437-1467.

Winkler, B., 2000. Which kind of transparency? On the need for clarity in monetary policy-making.

Yael, V.H., Ljungqvist, A., Lu, Y., 2007. Whom You Know Matters: Venture Capital Networks and Investment Performance. The Journal of Finance 62, 251-301.

Yin, X., Shanley, M., 2008. Industry determinants of the "merger versus alliance" decision. Academy of management review 33, 473-491.

You, H., Zhang, X.-j., 2009. Financial reporting complexity and investor underreaction to 10-K information. Review of Accounting Studies 14, 559-586. 


\section{Appendix A}

\begin{tabular}{|c|c|}
\hline Variables & Description \\
\hline \multicolumn{2}{|l|}{ Dependent variable } \\
\hline$C A R(-2,+2)$ firm & $\begin{array}{l}\text { The five-day market adjusted stock returns centered on the announcement } \\
\text { date of the firm. Source: CRSP }\end{array}$ \\
\hline \multicolumn{2}{|l|}{ Research variable } \\
\hline Fog_partner & $\begin{array}{l}\text { The fog index of the partner's annual } 10-\mathrm{K} \text { report where a higher number } \\
\text { indicates poor readability; this formula calculates the fog index as follows: } \\
0.4 \text { (average number of words+ percentage of complex words). Source: } \\
\text { http://webuser.bus.umich.edu/feng/ }\end{array}$ \\
\hline \multicolumn{2}{|l|}{ Control variables } \\
\hline Fog_firm & $\begin{array}{l}\text { The fog index of the firm's } 10-\mathrm{K} \text { report where a higher number indicates } \\
\text { poor readability; this formula calculates the fog index as follows: } 0.4 \\
\text { (average number of words+ percentage of complex words). Source: } \\
\text { http://webuser.bus.umich.edu/feng/ }\end{array}$ \\
\hline Ln(assets)_firm & $\begin{array}{l}\text { The natural logarithm of total assets (i.e., } \ln (\mathrm{AT}) \text { ) of the firm. Source: } \\
\text { COMPUSTAT }\end{array}$ \\
\hline $\mathrm{RO} A \_$firm & $\begin{array}{l}\text { The ratio of earnings before interest and tax divided by total assets (i.e., } \\
\text { EBITDA/AT) of the firm. Source: COMPUSTAT }\end{array}$ \\
\hline Debt-to-assets_firm & $\begin{array}{l}\text { The ratio of total liabilities and total assets (i.e., LT/AT) of the firm. } \\
\text { Source: COMPUSTAT }\end{array}$ \\
\hline Market-to-book_firm & $\begin{array}{l}\text { The ratio of the market value of equity plus total liabilities divided by total } \\
\text { assets (i.e., [PRCC_C*CSHO+LT]/AT) of the firm. Source: COMPUSTAT }\end{array}$ \\
\hline Intangibles_firm & $\begin{array}{l}\text { The ratio of intangibles divided by total assets (i.e., INTAN/AT) of the } \\
\text { firm. Source: COMPUSTAT }\end{array}$ \\
\hline Red_firm & $\begin{array}{l}\text { The ratio of R\&D expenditure divided by total assets (i.e., RDX/AT) of the } \\
\text { firm. Source: COMPUSTAT }\end{array}$ \\
\hline$R \& D$ dummy_firm & $\begin{array}{l}\text { Takes the value of one if R\&D expenses are not reported by the firm. } \\
\text { Source: COMPUSTAT }\end{array}$ \\
\hline Number_of_bus_seg_firm & The number of business segments of the firm. Source: COMPUSTAT \\
\hline Stock_volatility_firm & $\begin{array}{l}\text { The 12-month standard deviation of the stock returns calculated from the } \\
\text { monthly return data for the firm. Source: CRSP }\end{array}$ \\
\hline
\end{tabular}




\author{
Social_capital_firm \\ Alliance_exp_firm \\ Number_of_analyst_firm \\ Analyst_Est._Dispersion_firm \\ Ln(assets)_partner \\ ROA_partner
}

Debt-to-assets_partner

Market-to-book_partner

Intangibles_partner

RひD_partner

R\&D dummy_partner

Number_of_bus_seg_partner

Stock_volatility_fpartner

Social_capital_partner

Alliance_exp_partner

Number_of_analyst_partner

Analyst_Est._Dispersion_partner

Alliance_exp_together
The social capital of the region the firm is headquartered. Source: (Rupasingha et al., 2006)

An indicator variable that equals one if the firm has formed an alliance in the past based on our sample. Source: SDC

The number of analysts following the firm. Source: IBES

The standard deviation in the analysts' estimates for the firm. Source: IBES

The natural logarithm of total assets (i.e., ln (AT)) of the partner. Source: COMPUSTAT

The ratio of earnings before interest and tax divided by total assets (i.e., EBITDA/AT) of the partner. Source: COMPUSTAT

The ratio of total liabilities and total assets (i.e., LT/AT) of the partner. Source: COMPUSTAT

The ratio of the market value of equity plus total liabilities divided by total assets (i.e., [PRCC_C*CSHO+LT]/AT) of the partner. Source:

COMPUSTAT.

The ratio of intangibles divided by total assets (i.e., INTAN/AT) of the partner. Source: COMPUSTAT

The ratio of $\mathrm{R} \& \mathrm{D}$ expenditure divided by total assets (i.e., RDX/AT) of the partner. Source: COMPUSTAT

Equals one if R\&D expenses are not reported by the partner. Source: COMPUSTAT

The number of business segments of the partner. Source: COMPUSTAT

The 12-month standard deviation of the stock returns using monthly return data of the partner. Source: CRSP

The social capital of the region the partner is headquartered. Source:

(Rupasingha et al., 2006)

An indicator variable that equals one if the partner has formed an alliance in the past based on our sample. Source: SDC

The number of analysts following the partner. Source: IBES

The standard deviation in the analysts' estimates for the partner. Source: IBES

An indicator variable that equals one if the two firms had experience in forming an alliance, based on our sample. Source: SDC 


\section{Other variables used}

Withdrawn

Computer \& Software

High downloads_partner

CAR $(-2,+2)$ alliance value weighted

CAR (-2,+2)_alliance equally weighted

CAR(-1,+1)_firm

CAR(-1,+14)_firm

Flesch

Kincaid

FileSize

Fog_partner

(Average of last three years)

Fog_firm

(Average of last three years)
A dummy variable that takes the value of one if a deal is announced but is not completed. Source: SDC

An indicator variable that takes the value of one if the firm belongs to the Computer \& Software industry, and takes the value of zero if it belongs to the pharmaceutical industry. The firms that belong to the Computer (35) classification in the Fama-French 48 industry classifications or the following four-digit SICs are classified as belonging to the high-tech industry: 73707372 Services - computer programming and data processing, 7374-7374 Services - computer processing, data prep, 7375-7375 Services information retrieval services, 7376-7376 Services - computer facilities management service.

An indicator variable that is equal to 1 when the firm's partner's $10-\mathrm{K}$ are downloaded more than the median number of downloads one day after the alliance is announced. Source: SEC

The value weighted CAR $(-2,+2)$ for the two firms in the alliance. The value weights are based on the market value of the firm.

The average of the CAR $(-2,+2)$ for the two firms in the alliance.

Two-day market adjusted stock returns centered on the announcement date of the firm. Source: CRSP

Fifteen-day market adjusted stock returns starting one day before the announcement date and ending 14 days after the announcement. Source: CRSP

Measures reading ease. The formula is Flesch $=206.835-(1.015 *$ average number of words per sentence $)$ - (84.6* average number of syllables per word). Source: http://webuser.bus.umich.edu/feng/

Measures reading difficulty. The formula is Kincaid $=0.39 *$ (total words $/$ total sentences $)+11.8 *$ (total syllables / total words $)-15.59$. Source: http://webuser.bus.umich.edu/feng/

The size of the 10-K file. Source: http://www3.nd.edu/ mcdonald/

The mean of the fog index of the partner's $10-\mathrm{K}$ report for the last three years (t-1, t-2, and t-3). Source: http://webuser.bus.umich.edu/feng/

The mean of the fog index of the firm's $10-\mathrm{K}$ report for the last three years (t-1, t-2, and t-3). Source: http://webuser.bus.umich.edu/feng/ 


\section{EM_Jones3_partner}

\author{
G-index_firm \\ E-index_firm \\ \%_Independent_Director_firms \\ $\%$ _Number_of_Directors_firm \\ Managerial_ability_firm
}

Industry_adjusted_ROA_firm

G-index_partner

E-index_partner

$\%$ Independent_Director_partner

\%_Number_of_Directors_partner

Managerial_ability_partner

Industry_adjusted_ROA_firm
This variable is the sum of the absolute value of the discretionary accruals for the past three years for the partner. The discretionary accruals are calculated by using the modified (Jones, 1991) model. We calculate the total accruals (IBC-(OANCF- XIDOC)) by using the cash-flow approach as suggested by(Hribar and Collins, 2002). Source: COMPUSTAT

This is the G-index of the firm based on Gompers et al. (2003). Source: Riskmetrics

This is the E-index of the firm based on Bebchuk et al. (2009). Source: Riskmetrics

The percentage of independent directors on the firm's board. Source: Riskmetrics

The number of directors on the firm's board. Source: Riskmetrics

A measure of managerial ability of the firm's managers constructed by Demerjian et al. (2012). Source:

http://faculty.washington.edu/pdemerj/data.html.

Industry-adjusted return on assets of the firm. Source: COMPUSTAT

This is the G-index of the partner based on Gompers et al. (2003). Source: Riskmetrics

This is the E-index of the partner based on Bebchuk et al. (2009). Source: Riskmetrics

The percentage of independent directors on the partners' board. Source: Riskmetrics

The number of directors on the partners' board. Source: Riskmetrics

A measure of managerial ability of the partner's managers constructed by (Demerjian et al., 2012). Source:

http://faculty.washington.edu/pdemerj/data.html.

Industry-adjusted return on assets of the firm. Source: COMPUSTAT 


\section{Appendix B}

\section{Panel A}

\begin{tabular}{lc}
\hline & \# of alliances \\
\hline \hline Total number of alliances: & 11056 \\
Less (ones that involve private firms): & 7263 \\
Less (ones that involve joint venture): & 578 \\
Less ( financial or regulated firms): & 90 \\
Less (multiple partners): & 113 \\
Less ( fog index unavailable): & 1009 \\
Less ( CRSP Data unavailable): & 133 \\
Less ( IBES Data unavailable): & 289 \\
Total & 1581 \\
\hline
\end{tabular}

\section{Panel B}

\begin{tabular}{cc}
\hline Year & Alliances \\
\hline \hline 1995 & 38 \\
1996 & 89 \\
1997 & 228 \\
1998 & 218 \\
1999 & 213 \\
2000 & 149 \\
2001 & 94 \\
2002 & 80 \\
2003 & 98 \\
2004 & 81 \\
2005 & 94 \\
2006 & 73 \\
2007 & 52 \\
2008 & 28 \\
2009 & 19 \\
2010 & 6 \\
2011 & 16 \\
2012 & 5 \\
Total & 1581 \\
\hline
\end{tabular}




\section{Panel C}

\begin{tabular}{lrr}
\hline & \% of & \\
Alliance Type & Alliances & Number \\
\hline \hline License_alliance & $23.91 \%$ & 378 \\
ReD_alliance & $17.33 \%$ & 274 \\
Funding_alliance & $0.44 \%$ & 7 \\
Manufacturing_alliance & $9.74 \%$ & 154 \\
Marketing_alliance & $22.26 \%$ & 352 \\
Supply_alliance & $1.96 \%$ & 31 \\
Technology_alliance & $16.51 \%$ & 261 \\
Royalty_alliance & $1.71 \%$ & 27 \\
Not Specified & $6.14 \%$ & 97 \\
Total & $100.00 \%$ & 1581 \\
\hline
\end{tabular}

\section{Panel D}

\begin{tabular}{cc}
\hline Frequency of \# of alliances & $\%$ of the sample \\
\hline \hline 1 & $55.60 \%$ \\
2 & $20.11 \%$ \\
3 & $9.71 \%$ \\
4 & $5.03 \%$ \\
5 & $2.17 \%$ \\
6 or greater & $7.37 \%$ \\
\hline Total & $100.00 \%$ \\
\hline
\end{tabular}

\section{Panel E}

\begin{tabular}{lcc|cr}
\hline \hline & \multicolumn{2}{c|}{ Alliance Sample } & \multicolumn{2}{c}{ Compustat Firms } \\
& Mean & Std. Dev & Mean & Std. Dev \\
Fog_firm & 19.577 & 1.580 & 19.438 & 1.222 \\
Ln(Assets)_firm & 7.079 & 2.556 & 4.769 & 2.804 \\
ROA_firm & 0.072 & 0.225 & 0.012 & 0.280 \\
Debt-to-Assets_firm & 0.500 & 0.263 & 0.513 & 0.546 \\
Market-to-Book_firm & 2.350 & 5.142 & 1.022 & 1.548 \\
Intangibles_firm & 0.099 & 0.151 & 0.114 & 0.178 \\
R\&D_firm & 0.091 & 0.166 & 0.124 & 0.085 \\
R\&DDummy_firm & 0.246 & 0.418 & 0.482 & 0.500 \\
Number_of_segments_firm & 2.943634 & 5.016 & 3.265 & 3.551 \\
Stock_volatility_firm & 0.149 & 0.112 & 0.136 & 0.106 \\
Social_capital_firm & -0.545 & 0.793 & -0.503 & 0.909 \\
\hline
\end{tabular}


Figure 1: The number of downloads of 10-Ks increases around the time of strategic alliance's announcement

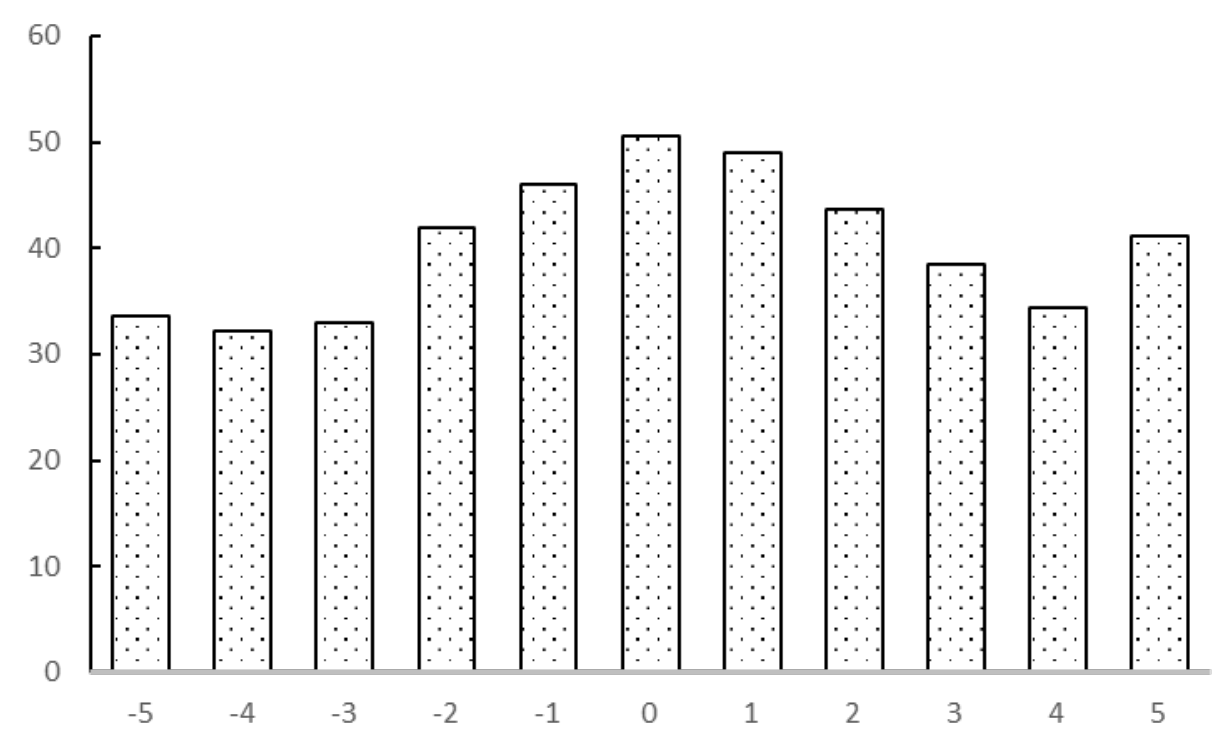

Notes on Figure 1 This graph represents the number of $10-\mathrm{K}$ downloads five days before and five days after the announcement of an alliance. The $\mathrm{y}-$ axis represents the average number of downloads, the $\mathrm{x}$-axis represents the days before and after the alliance, zero is the day of the alliance announcements. The data are available only after February 14, 2003, and were collected from https://www.sec.gov/data/edgar-log-file-data-set.html. 
Figure 2

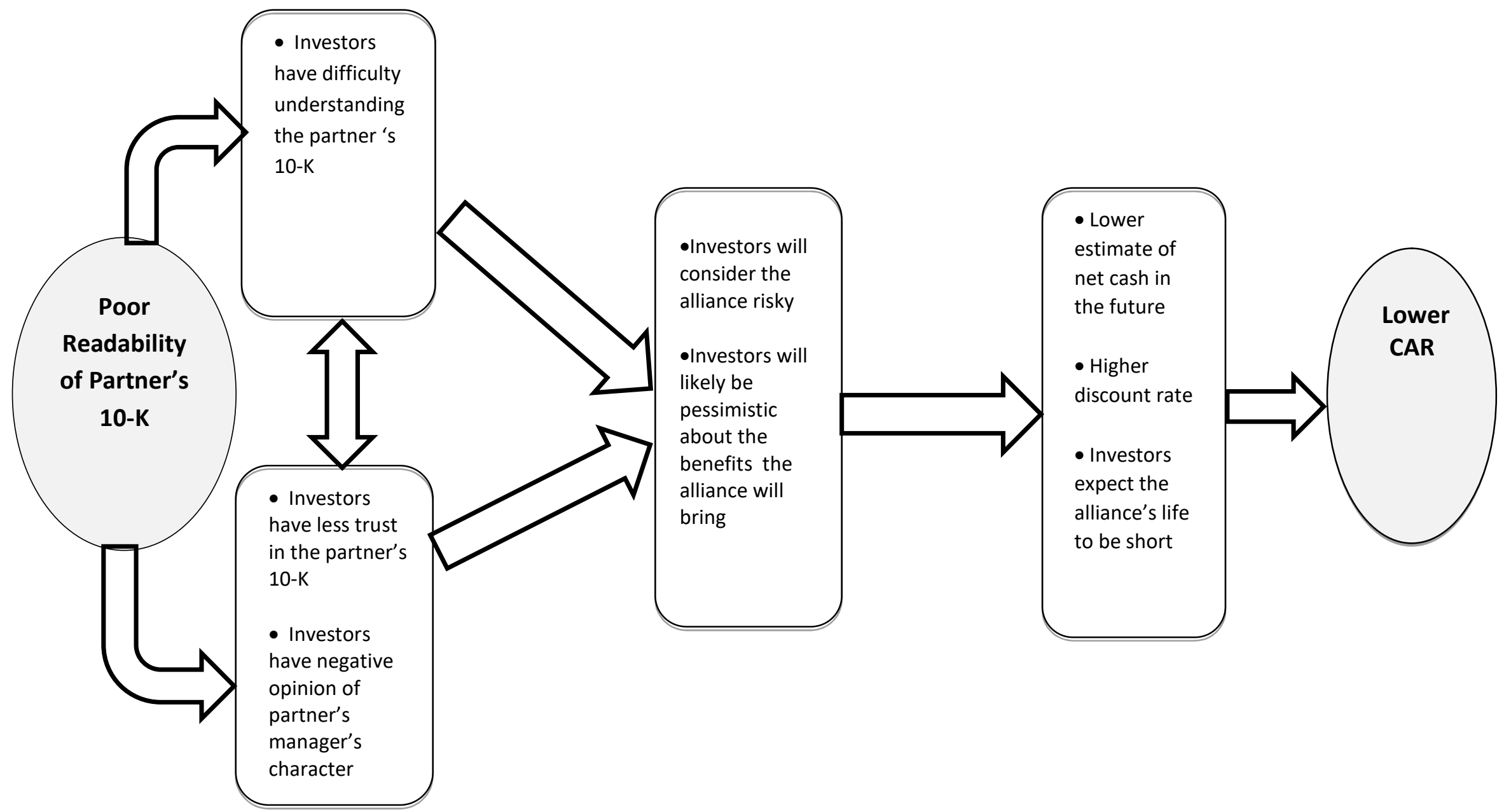

Notes on Figure 2: This figure summarizes how the poor readability of the partner's 10-K report might be associated with a lower CAR around the time the firm announces its alliance 
Figure 3

Univariate Analysis: The CAR at the announcement of a strategic alliance is lower when the partner's $10-\mathrm{K}$ report is less readable

\section{Panel A}

\section{CAR (-2,+2)_firm}

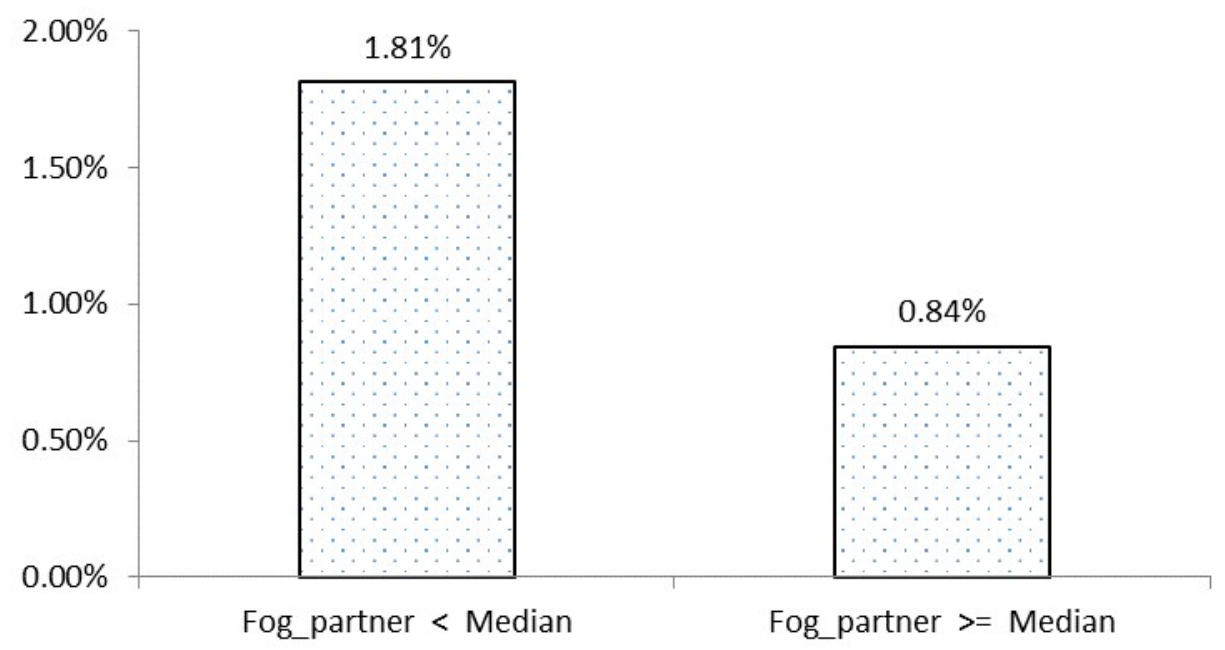

Panel B

\section{CAR $(-2,+2)$ firm}

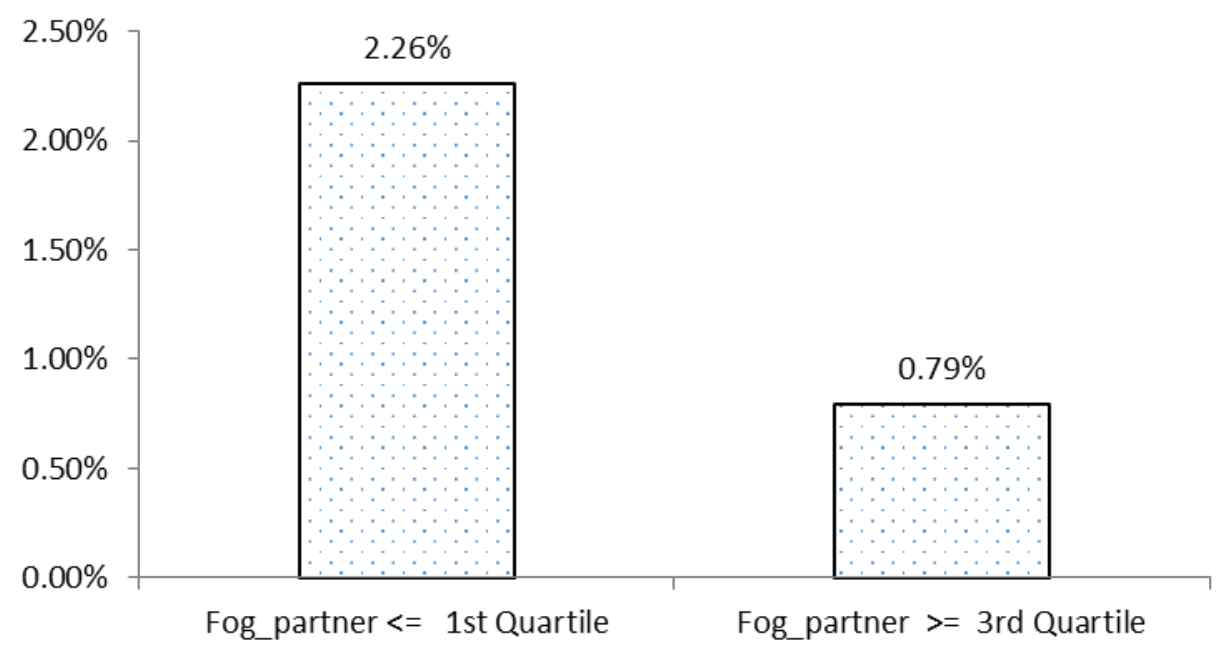

Notes on Figure 3: Panel A presents the mean of $C A R(-2,+2)$ firm for the five-day window around the day the firm announces a strategic alliance for two subsamples: one where Fog_Partner < median, and one where Fog_Partner $\geq$ median. Panel B presents the same except that the sample is divided into three equal subsamples groups where only the highest and lowest quartiles are used. The mean $C A R(-2,+2)$ firm are for those in the lowest quartile and the highest quartile. 
Table 1: Summary Statistics

\begin{tabular}{|c|c|c|c|c|c|c|c|c|}
\hline & $\mathrm{N}$ & Mean & Std. Dev & Median & $\mathrm{p} 25$ & $\mathrm{p} 75$ & Min & $\operatorname{Max}$ \\
\hline CAR (-2,+2)_firm & 3502 & 0.013 & 0.108 & 0.007 & -0.034 & 0.050 & -0.687 & 1.033 \\
\hline Fog_partner & 3502 & 19.671 & 1.453 & 19.524 & 18.726 & 20.418 & 8.378 & 30.791 \\
\hline Fog firm & 3502 & 19.665 & 1.594 & 19.524 & 18.726 & 20.417 & 8.378 & 30.791 \\
\hline Ln(Assets)_firm & 3502 & 7.028 & 2.549 & 7.056 & 5.049 & 9.290 & 0.735 & 13.590 \\
\hline $\mathrm{RO} A \_$firm & 3502 & 0.070 & 0.243 & 0.123 & 0.029 & 0.189 & -0.967 & 0.431 \\
\hline Debt-to-Assets_firm & 3502 & 0.476 & 0.266 & 0.437 & 0.248 & 0.611 & 0.046 & 0.980 \\
\hline Market-to-Book_firm & 3502 & 2.625 & 5.567 & 0.932 & 0.812 & 2.416 & 0.051 & 7.916 \\
\hline Intangibles_firm & 3502 & 0.103 & 0.159 & 0.022 & 0.007 & 0.136 & 0.000 & 0.765 \\
\hline$R \circlearrowleft D_{\text {firm }}$ & 3502 & 0.102 & 0.185 & 0.079 & 0.022 & 0.142 & 0.000 & 0.985 \\
\hline R\&D Dummy_firm & 3502 & 0.158 & 0.398 & 0.000 & 0.000 & 0.000 & 0.000 & 1.000 \\
\hline Number_of_bus_seg_firm & 3502 & 2.828 & 5.323 & 1.000 & 1.000 & 3.000 & 1.000 & 24.000 \\
\hline Stock_volatility_firm & 3502 & 0.144 & 0.119 & 0.115 & 0.081 & 0.182 & 0.029 & 0.722 \\
\hline Social_capital_firm & 3502 & -0.581 & 0.790 & -0.551 & -1.177 & 0.024 & -2.219 & 2.398 \\
\hline Alliance_exp_firm & 3502 & 0.439 & 0.496 & 0 & 0 & 1 & 0 & 1 \\
\hline Number_of_analyst_firm & 3502 & 5.201 & 9.811 & 5 & 2 & 14 & 1 & 51 \\
\hline Analyst_Est._Dispersion_firm & 3502 & 0.036 & 0.848 & 0.0312 & 0.0127 & 0.0813 & 0 & 1.57 \\
\hline Ln(Assets)_partner & 3502 & 6.974 & 2.254 & 5.049 & 9.290 & 8.024 & 0.735 & 13.590 \\
\hline $\mathrm{RO} A \_$partner & 3502 & 0.073 & 0.290 & 0.123 & 0.029 & 0.189 & -0.967 & 0.431 \\
\hline Debt-to-Assets_partner & 3502 & 0.426 & 0.251 & 0.436 & 0.249 & 0.611 & 0.046 & 0.980 \\
\hline Market-to-Book_partner & 3502 & 2.577 & 5.041 & 0.922 & 0.922 & 0.922 & 0.051 & 7.916 \\
\hline Intangibles_partner & 3502 & 0.098 & 0.133 & 0.022 & 0.007 & 0.136 & 0.000 & 0.765 \\
\hline R\&D_partner & 3502 & 0.151 & 0.139 & 0.079 & 0.022 & 0.142 & 0.000 & 0.985 \\
\hline R\&D Dummy_partner & 3502 & 0.165 & 0.368 & 0.000 & 0.000 & 0.000 & 0.000 & 1.000 \\
\hline Number_of_bus_seg_partner & 3502 & 2.229 & 2.640 & 1.000 & 1.000 & 2.000 & 1.000 & 24.000 \\
\hline Stock_volatility_partner & 3502 & 0.130 & 0.085 & 0.119 & 0.082 & 0.181 & 0.029 & 0.722 \\
\hline Social_capital_partner & 3502 & -0.502 & 0.534 & -0.455 & -1.118 & 0.023 & -2.219 & 2.398 \\
\hline Alliance_exp_partner & 3502 & 0.449 & 0.481 & 0 & 0 & 1 & 0 & 1 \\
\hline Alliance_exp_together & 3502 & 0.027 & 0.031 & 0 & 0 & 0 & 0 & 1 \\
\hline Number_of_analyst_partner & 3502 & 5.578 & 9.8735 & 5 & 2 & 14 & 1 & 51 \\
\hline Analyst_Est._Dispersion_partner & 3502 & 0.049 & 0.8057 & 0.04 & 0.01 & 0.0821 & 0 & 1.57 \\
\hline
\end{tabular}

Notes on Table 1: This table presents the summary statistics of the sample used in the study. The descriptions of the variables are in Appendix A. All of the continuous variables are winsorized at the 0.5 and the 99.5 percentiles. 
Table 2: Readability of 10-K report and cumulative abnormal stock returns

Panel A: The main results show that the poor readability of the partner's 10-K report is associated with lower cumulative abnormal stock returns

\begin{tabular}{|c|c|c|c|}
\hline \multirow{4}{*}{ Fog_partner } & $(1)$ & (2) & (3) \\
\hline & \multicolumn{3}{|c|}{ Dependent variable $=C A R(-2,+2)$ firm } \\
\hline & -0.0036 & -0.0035 & -0.0026 \\
\hline & $(0.017)^{* *}$ & $(0.025)^{* *}$ & $(0.048) * *$ \\
\hline \multirow{2}{*}{ Fog_firm } & -0.0019 & -0.0016 & \\
\hline & $(0.342)$ & $(0.399)$ & \\
\hline \multirow[t]{2}{*}{ Ln(Assets)_firm } & -0.0085 & -0.0082 & \\
\hline & $(0.001)^{* * *}$ & $(0.002)^{* * *}$ & \\
\hline \multirow[t]{2}{*}{$\mathrm{RO} A \_$firm } & -0.0835 & -0.0815 & \\
\hline & $(0.005)^{* * *}$ & $(0.008)^{* * *}$ & \\
\hline \multirow[t]{2}{*}{ Debt-to-Assets_firm } & 0.0071 & 0.0077 & \\
\hline & $(0.239)$ & $(0.136)$ & \\
\hline \multirow[t]{2}{*}{ Market-to-Book_firm } & -0.0009 & -0.0007 & \\
\hline & $(0.014)^{* *}$ & $(0.056)^{*}$ & \\
\hline \multirow[t]{2}{*}{ Intangibles_firm } & -0.0130 & -0.0089 & \\
\hline & $(0.460)$ & $(0.592)$ & \\
\hline \multirow[t]{2}{*}{$R \otimes D \_f i r m$} & 0.0091 & 0.0109 & \\
\hline & $(0.672)$ & $(0.689)$ & \\
\hline \multirow[t]{2}{*}{ R®D Dummy_firm } & -0.0053 & -0.0052 & \\
\hline & $(0.476)$ & $(0.527)$ & \\
\hline \multirow{2}{*}{ Number_of_bus_segmens_firm } & 0.0005 & 0.0004 & \\
\hline & $(0.089)^{*}$ & $(0.140)$ & \\
\hline \multirow[t]{2}{*}{ Stock_volatility_firm } & -0.0578 & -0.0596 & \\
\hline & $(0.052)^{*}$ & $(0.040)^{* *}$ & \\
\hline \multirow[t]{2}{*}{ Social_capital_firm } & -0.0056 & -0.0050 & \\
\hline & $(0.177)$ & $(0.238)$ & \\
\hline \multirow[t]{2}{*}{ Alliance_exp_firm } & -0.0092 & -0.0089 & \\
\hline & $(0.010)^{* *}$ & $(0.009)^{* * *}$ & \\
\hline \multirow[t]{2}{*}{ Number_of_analyst_firm } & 0.0008 & 0.0008 & \\
\hline & $(0.085)^{*}$ & $(0.086)^{*}$ & \\
\hline \multirow[t]{2}{*}{ Analyst_Est._Dispersion_firm } & 0.0004 & 0.0004 & \\
\hline & $(0.169)$ & $(0.125)$ & \\
\hline \multirow[t]{2}{*}{ Ln(Assets)_partner } & 0.0006 & & \\
\hline & $(0.456)$ & & \\
\hline \multirow[t]{2}{*}{$R O A \_p a r t n e r$} & -0.0093 & & \\
\hline & $(0.311)$ & & \\
\hline \multirow[t]{2}{*}{ Debt-to-Assets_partner } & -0.0028 & & \\
\hline & $(0.526)$ & & \\
\hline \multirow[t]{2}{*}{ Market-to-Book_partner } & -0.0000 & & \\
\hline & $(0.298)$ & & \\
\hline \multirow[t]{2}{*}{ Intangibles_partner } & -0.0088 & & \\
\hline & $(0.455)$ & & \\
\hline \multirow[t]{2}{*}{ R\&D_partner } & -0.0068 & & \\
\hline & $(0.674)$ & & \\
\hline ReD Dummy_partner & -0.0041 & & \\
\hline
\end{tabular}




$\begin{array}{lc}\text { Number_of_bus_segment_partner } & (0.990) \\ & 0.0003 \\ \text { Stock_volatility_partner } & (0.346) \\ & -0.0253 \\ \text { Social_capital_partner } & (0.100) \\ & -0.0014 \\ \text { Alliance_exp_partner } & (0.540) \\ & 0.0234 \\ \text { Alliance_exp_together } & (0.015)^{* *} \\ & -0.0054 \\ \text { Number_of_analyst_partner } & (0.065)^{*} \\ & 0.0010 \\ \text { Analyst_Est._Dispersion_partner } & (0.000)^{* * *} \\ & -0.0001 \\ & (0.274)\end{array}$

Alliance Type Dummies

YES

Industry Dummies

YES

Year Dummies

YES

Observations

3162

0.08

NO

NO

YES

YES

YES

YES

R-squared

3162

3162

0.07

0.03 
Panel B: The main results are robust when using an alternative measure for readability

\begin{tabular}{|c|c|c|c|c|c|c|}
\hline & (1) & $(2)$ & (3) & (4) & $(5)$ & (6) \\
\hline & \multicolumn{6}{|c|}{ Dependent variable $=C A R(-2,+2) \_$firm } \\
\hline Kincaid_partner & $\begin{array}{l}-0.0033 \\
(0.021) * *\end{array}$ & $\begin{array}{l}-0.0023 \\
(0.042) * *\end{array}$ & & & & \\
\hline Flesch_partner & & & $\begin{array}{l}0.0007 \\
(0.045)^{* *}\end{array}$ & $\begin{array}{l}0.0003 \\
(0.072) *\end{array}$ & & \\
\hline FileSize_partner & & & & & $\begin{array}{l}-0.0122 \\
(0.003) * * *\end{array}$ & $\begin{array}{l}-0.0051 \\
(0.053) *\end{array}$ \\
\hline Control variables & Yes & No & Yes & No & Yes & No \\
\hline Alliance Type Dummies & Yes & No & Yes & No & Yes & No \\
\hline Industry Dummies & Yes & Yes & Yes & Yes & Yes & Yes \\
\hline Year Dummies & Yes & Yes & Yes & Yes & Yes & Yes \\
\hline Observations & 3162 & 3162 & 3162 & 3162 & 3162 & 3162 \\
\hline R-squared & 0.08 & 0.01 & 0.08 & 0.01 & 0.07 & 0.01 \\
\hline
\end{tabular}


Panel C: The association between the readability of the $10-\mathrm{K}$ and CAR is robust when we use equally or value weighted variables

\begin{tabular}{|c|c|c|}
\hline & $\begin{array}{c}(1) \\
\text { Dependent variabl }\end{array}$ & 2)_alliance \\
\hline Fog - value (equally) weighted & $\begin{array}{c}\text { Value Weighted } \\
-0.0032 \\
(0.007)^{* * *}\end{array}$ & $\begin{array}{c}\text { Equally Weighted } \\
-0.0033 \\
(0.044)^{* *}\end{array}$ \\
\hline Ln(assets) - value (equally) weighted & $\begin{array}{c}-0.0004 \\
(0.416)\end{array}$ & $\begin{array}{l}-0.0009 \\
(0.302)\end{array}$ \\
\hline $\mathrm{ROA}$ - value (equally) weighted & $\begin{array}{l}-0.0076 \\
(0.035)^{* *}\end{array}$ & $\begin{array}{l}-0.0089 \\
(0.227)\end{array}$ \\
\hline Debt-to-assets - value (equally) weighted & $\begin{array}{c}-0.0015 \\
(0.806)\end{array}$ & $\begin{array}{l}-0.0056 \\
(0.339)\end{array}$ \\
\hline Market-to-book - value (equally) weighted & $\begin{array}{c}0.0000 \\
(0.038)^{* *}\end{array}$ & $\begin{array}{l}0.0000 \\
(0.288)\end{array}$ \\
\hline Intangibles - value (equally) weighted & $\begin{array}{l}-0.0288 \\
(0.046)^{* *}\end{array}$ & $\begin{array}{l}-0.0137 \\
(0.283)\end{array}$ \\
\hline R\&D - value (equally) weighted & $\begin{array}{c}0.0039 \\
(0.064)^{*}\end{array}$ & $\begin{array}{l}0.0121 \\
(0.300)\end{array}$ \\
\hline R\&D dummy - value (equally) weighted & $\begin{array}{c}-0.0166 \\
(0.103)\end{array}$ & $\begin{array}{l}-0.0057 \\
(0.171)\end{array}$ \\
\hline Number_of_bus_seg - value (equally) weighted & $\begin{array}{l}0.0005 \\
(0.181)\end{array}$ & $\begin{array}{l}0.0002 \\
(0.516)\end{array}$ \\
\hline Stock_volatility - value (equally) weighted & $\begin{array}{c}-0.0138 \\
(0.687)\end{array}$ & $\begin{array}{r}-0.0280 \\
(0.213)\end{array}$ \\
\hline Social_capital-value (equally) weighted & $\begin{array}{c}-0.0055 \\
(0.108)\end{array}$ & $\begin{array}{l}-0.0036 \\
(0.066)^{*}\end{array}$ \\
\hline Alliance_exp-value (equally) weighted & $\begin{array}{l}-0.0088 \\
(0.007)^{* * *}\end{array}$ & $\begin{array}{l}-0.0086 \\
(0.056) *\end{array}$ \\
\hline Alliance_exp_together & $\begin{array}{r}-0.0039 \\
(0.449)\end{array}$ & $\begin{array}{l}-0.0045 \\
(0.373)\end{array}$ \\
\hline Number_of_analyst-value (equally) weighted & $\begin{array}{c}-0.0007 \\
(0.001)^{* * *}\end{array}$ & $\begin{array}{c}-0.0008 \\
(0.000)^{* * *}\end{array}$ \\
\hline \multirow[t]{2}{*}{$\begin{array}{l}\text { Analyst_Est._Dispersion - value (equally) } \\
\text { weighted }\end{array}$} & 0.0005 & 0.0005 \\
\hline & $(0.086)^{*}$ & $(0.064)^{*}$ \\
\hline $\begin{array}{l}\text { Alliance Type Dummies } \\
\text { Industry Dummies } \\
\text { Year Dummies } \\
\text { Observations } \\
\text { R-squared }\end{array}$ & $\begin{array}{l}\text { Yes } \\
\text { No } \\
\text { Yes } \\
1581 \\
0.04\end{array}$ & $\begin{array}{c}\text { Yes } \\
\text { No } \\
\text { Yes } \\
1581 \\
0.04\end{array}$ \\
\hline
\end{tabular}


Panel D: The association between the readability of the $10-\mathrm{K}$ and CAR is robust when we use propensity score matching rather than an OLS

\begin{tabular}{|c|c|c|c|c|c|c|c|c|}
\hline \multirow[b]{3}{*}{$C A R(-2,+2) \_$firm } & \multicolumn{3}{|c|}{$\begin{array}{l}\text { Low Partner Readability } \\
\text { (Treated Group) }\end{array}$} & \multicolumn{3}{|c|}{$\begin{array}{l}\text { High Partner Readability } \\
\text { (Matched Group) }\end{array}$} & \multirow[b]{2}{*}{$\begin{array}{c}\mathrm{T}- \\
\text { statistics }\end{array}$} & \multirow[b]{2}{*}{$\begin{array}{c}\mathrm{p}^{-} \\
\text {value }\end{array}$} \\
\hline & Mean & Median & $\begin{array}{l}\text { Std. } \\
\text { Dev }\end{array}$ & Mean & Median & $\begin{array}{l}\text { Std. } \\
\text { Dev }\end{array}$ & & \\
\hline & 0.005 & 0.001 & 0.131 & 0.019 & 0.007 & 0.122 & 3.436 & 0.000 \\
\hline $\mathrm{ROA \_ firm}$ & 0.091 & 0.135 & 0.198 & 0.080 & 0.123 & 0.208 & 1.369 & 0.171 \\
\hline Debt-to-Assets_firm & 0.434 & 0.416 & 0.229 & 0.445 & 0.418 & 0.254 & 1.120 & 0.263 \\
\hline Market-to-Book_firm & 3.138 & 0.949 & 6.528 & 3.087 & 0.949 & 6.607 & 0.195 & 0.845 \\
\hline Intangibles_firm & 0.080 & 0.022 & 0.121 & 0.091 & 0.022 & 0.143 & 0.788 & 0.425 \\
\hline$R \otimes D \_f i r m$ & 0.100 & 0.077 & 0.117 & 0.107 & 0.086 & 0.119 & 1.006 & 0.308 \\
\hline R\&D Dummy_firm & 0.135 & 0.000 & 0.342 & 0.142 & 0.000 & 0.349 & 0.473 & 0.637 \\
\hline Number_of_bus_segment_firm & 4.550 & 3.000 & 5.440 & 4.713 & 3.000 & 5.447 & 0.756 & 0.450 \\
\hline Stock_volatility_firm & 0.168 & 0.131 & 0.118 & 0.178 & 0.147 & 0.126 & 0.209 & 0.745 \\
\hline Social_capital_firm & -0.617 & -0.650 & 0.788 & -0.634 & -0.732 & 0.748 & 0.550 & 0.582 \\
\hline Allianc_exp_firm & 0.594 & 1.000 & 0.491 & 0.591 & 1.000 & 0.492 & 0.121 & 0.904 \\
\hline Number_of_analyst_firm & 17.098 & 15.000 & 12.633 & 16.920 & 14.000 & 12.331 & 0.360 & 0.719 \\
\hline Analyst_Est._Dispersion_firm & 0.083 & 0.030 & 0.180 & 0.236 & 0.030 & 4.219 & 1.292 & 0.197 \\
\hline
\end{tabular}


Panel E: Difference-in-difference estimation using the plain English Initiative (PEI) of 1998

\begin{tabular}{lcc}
\hline \hline & $(1)$ & $(2)$ \\
& $\begin{array}{c}\text { Dependent variable }=C A R \\
1\end{array}$ & $(-2,+2)$ firm \\
TreatGroup & Dependent variable $=C A R(-2,+2)$ firm \\
& -0.0116 & $1997 \& 1999$ \\
TreatGroup* Year 1999 & $(0.034)^{* *}$ & -0.0252 \\
& 0.0204 & $(0.000)^{* * *}$ \\
Year 1999 & $(0.046)^{* *}$ & 0.0201 \\
& -0.0260 & $(0.006)^{* * *}$ \\
Control variables & $(0.024)^{* *}$ & -0.0362 \\
Industry Dummies & & $(0.001)^{* * *}$ \\
Year Dummies & YES & No \\
Observations & YES & No \\
R-squared & YES & No \\
\hline
\end{tabular}


Panel F: The effect of the readability of a partner's 10-K on a firm's CAR is stronger when the partner's 10-K is downloaded to a greater extent

\begin{tabular}{|c|c|c|c|c|c|c|}
\hline & (1) & $(2)$ & $\begin{array}{c}\text { (3) } \\
\text { endent variable }\end{array}$ & $=C^{(4)}{ }_{(-2,+}$ & rm & (6) \\
\hline Fog_partner & $\begin{array}{c}-0.0047 \\
(0.043) * *\end{array}$ & $\begin{array}{c}-0.0045 \\
(0.046)^{* *}\end{array}$ & $\begin{array}{c}-0.002 \\
(0.032)^{* *}\end{array}$ & $\begin{array}{l}-0.0027 \\
(0.049) * *\end{array}$ & $\begin{array}{l}-0.0040 \\
(0.043) * *\end{array}$ & $\begin{array}{l}-0.0028 \\
(0.042)^{* *}\end{array}$ \\
\hline High downloads_partner & $\begin{array}{c}0.2612 \\
(0.000)^{* * *}\end{array}$ & $\begin{array}{c}0.2440 \\
(0.003)^{* * *}\end{array}$ & $\begin{array}{c}0.1768 \\
(0.002)^{* * *}\end{array}$ & & & \\
\hline Fog_partner*High downloads_partner & $\begin{array}{c}-0.0103 \\
(0.000)^{* * *}\end{array}$ & $\begin{array}{c}-0.0105 \\
(0.002) * * *\end{array}$ & $\begin{array}{c}-0.0097 \\
(0.001)^{* * *}\end{array}$ & & & \\
\hline Downloads_partner & & & & $\begin{array}{l}0.0008 \\
(0.074)^{*}\end{array}$ & $\begin{array}{l}0.0010 \\
(0.094) *\end{array}$ & $\begin{array}{l}0.0014 \\
(0.013)^{* *}\end{array}$ \\
\hline Fog_partner*Downloads_partner & & & & $\begin{array}{l}-0.0001 \\
(0.014)^{* *}\end{array}$ & $\begin{array}{l}-0.0001 \\
(0.048)^{* *}\end{array}$ & $\begin{array}{l}-0.0001 \\
(0.011)^{* *}\end{array}$ \\
\hline Control variables & Yes & Firm Only & No & Yes & Firm Only & No \\
\hline Alliance Type Dummies & Yes & No & No & Yes & No & No \\
\hline Industry Dummies & Yes & Yes & Yes & Yes & Yes & Yes \\
\hline Year Dummies & Yes & Yes & Yes & Yes & Yes & Yes \\
\hline Observations & 886 & 886 & 886 & 886 & 886 & 886 \\
\hline R-squared & 0.076 & 0.063 & 0.024 & 0.073 & 0.061 & 0.023 \\
\hline
\end{tabular}


Notes on Table 2: Panel A presents the main results. It shows that the higher the fog index of the partner's annual $10-\mathrm{K}$ report, the lower the abnormal stock returns are when the firm announces its strategic alliance. A higher fog index means a more unreadable $10-\mathrm{K}$ report. The coefficients are from an OLS analysis. The $p$-values in parentheses are based on standard errors clustered by firm and alliance ID. Panel B shows that results in Panel A are robust when using alternative measures of readability (Kincaid, Flesch and FileSize). Higher values of Kincaid and File Size represent poor readability. Higher values of Flesch means better readability. Panel $\mathrm{C}$ reports results where we use value and equally weighted variables to construct one measure for each alliance. In column 1 the results are from an OLS where all variables are value weighted. In column 2 we present the results when all variables are equally weighted. The $p$-values are based on robust standard errors. The control variables are as specified in equation 1 (i.e., all variables used in Column 1 of Panel A in Table 2). Panel D presents the results of propensity score matching with replacements. The treated group is the group where Fog partner is less than the median. The matched group is constructed using propensity score matching. Panel E presents of the difference-in-difference analysis. The TreatGroup is an indicator variable that equals one if it belongs to the group that has poor readability in 1997, and zero if it belongs to the control group - the matched set of firms that are similar in other respects except that they belong to the group with higher readability. The control variables are as specified in equation 1 (i.e., all variables used in Column 1 of Panel A in Table 2). Panel F shows that the effect of Fog partner on CAR $(-2,+2)$ firm is much stronger when the partner's $10-\mathrm{K}$ is downloaded more. High downloads_partner takes a value of one when the $10-\mathrm{K}$ of the firm's partner is downloaded more than the median number of times on the day after the alliance is announced, and zero otherwise. Downloads_partner is the number of times the partner's $10-\mathrm{K}$ was downloaded the day after the alliance is announced. Firm Only means we control for the firm-level characteristics of the firm, but not the partner's. The sample size is smaller because the 10-K download data is only available from February 14, 2003, onwards. The t-stats and the $p$-values test whether the means for the two groups are equal. All of the continuous variables are winsorized at the 0.5 and the 99.5 percentiles. The ${ }^{* * *}$, **, and * represent significance at the 1, 5, and $10 \%$ levels respectively. The $p$-values are based on standard errors clustered by alliance and firm and are in parentheses. All variables are described in Appendix A. 
Table 3: Moderation tests

Panel A: The effect of the readability of the partner's annual 10-K report on firms in the high-tech industry compared to those in the pharmaceutical industry.

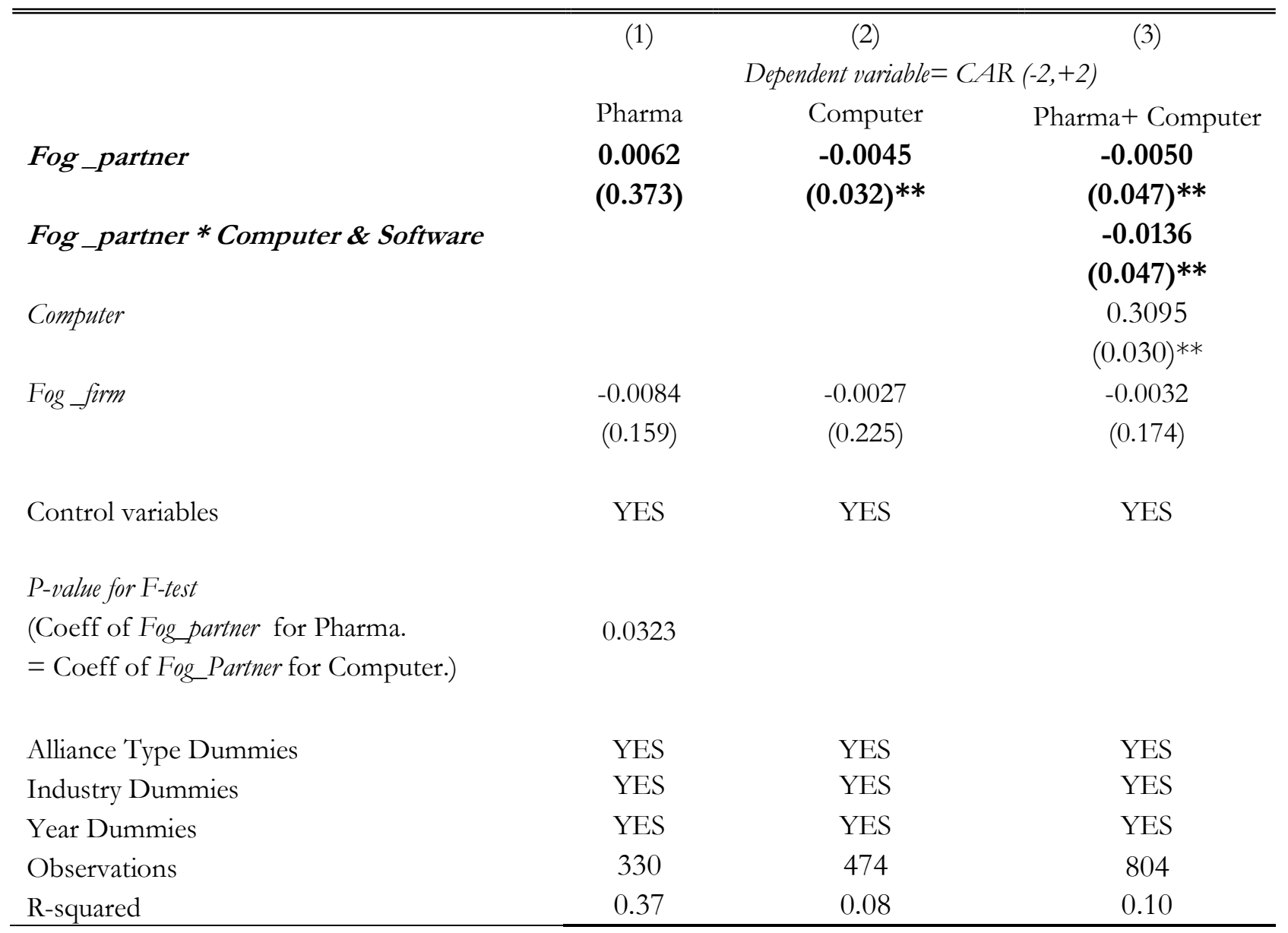


Panel B: The effect of the readability of the partner's annual 10-K on the alliances that occur between firms from different industries.

\begin{tabular}{|c|c|c|c|}
\hline & (1) & (2) & (3) \\
\hline & \multicolumn{3}{|c|}{ Dependent variable $=C A R(-2,+2)$ firm } \\
\hline & Diff Inds. & Same Inds. & All Firms \\
\hline \multirow[t]{2}{*}{ Fog_partner } & -0.0045 & -0.0053 & -0.0047 \\
\hline & $(0.014) * *$ & $(0.306)$ & $(0.016) * *$ \\
\hline \multirow[t]{2}{*}{ Fog_partner * Horizontal } & & & 0.0033 \\
\hline & & & $(0.431)$ \\
\hline \multirow[t]{2}{*}{ Horizontal } & & & -0.0694 \\
\hline & & & $(0.407)$ \\
\hline \multirow[t]{2}{*}{ Fog_firm } & 0.0024 & -0.0039 & -0.0024 \\
\hline & $(0.179)$ & $(0.428)$ & $(0.166)$ \\
\hline Control variables & YES & YES & YES \\
\hline \multicolumn{4}{|l|}{ P-value for F-test } \\
\hline \multirow{2}{*}{$\begin{array}{l}\text { (Coeff of Fog partner for Diff Inds. } \\
=\text { Coeff of Fog_Partner for Same Inds.) }\end{array}$} & 0.049 & & \\
\hline & & & \\
\hline Industry Dummies & YES & YES & YES \\
\hline Year Dummies & YES & YES & YES \\
\hline Observations & 2738 & 424 & 3162 \\
\hline R-squared & 0.09 & 0.14 & 0.08 \\
\hline
\end{tabular}


Panel C: The effect of the readability of the partner's annual 10-K report on alliances in the pre-SarbanesOxley period

\begin{tabular}{|c|c|c|c|}
\hline & (1) & (2) & (3) \\
\hline & \multicolumn{3}{|c|}{ Dependent variable $=C A R(-2,+2) \_$firm } \\
\hline & Pre-SOX & Post-SOX & Pre-SOX + Post-SOX \\
\hline & $2000-2002$ & 2003-2005 & $2000-2005$ \\
\hline \multirow[t]{2}{*}{ Fog_partner } & -0.0086 & 0.0001 & -0.0062 \\
\hline & $(0.029) * *$ & $(0.954)$ & $(0.007) * * *$ \\
\hline \multirow[t]{2}{*}{ Fog_partner * Year 2002} & & & 0.0093 \\
\hline & & & $(0.039)^{* *}$ \\
\hline \multirow[t]{2}{*}{ Year 2002} & & & -0.1337 \\
\hline & & & $(0.100)^{*}$ \\
\hline \multirow[t]{2}{*}{ Fog_firm } & -0.0012 & -0.0055 & -0.0023 \\
\hline & $(0.640)$ & $(0.202)$ & $(0.178)$ \\
\hline Control variables & YES & YES & YES \\
\hline \multicolumn{4}{|l|}{ P-value for F-test } \\
\hline \multirow{2}{*}{$\begin{array}{l}\text { (Coeff of Fog_partner for Pre-SOX. } \\
=\text { Coeff of Fog_Partner for Post-SOX.) }\end{array}$} & 0.0321 & & \\
\hline & & & \\
\hline Industry Dummies & YES & YES & YES \\
\hline Year Dummies & YES & YES & YES \\
\hline Observations & 646 & 544 & 1190 \\
\hline R-squared & 0.17 & 0.09 & 0.12 \\
\hline
\end{tabular}

Notes on Table 3: This table shows that the effect of Fog_partner is stronger when investors consider the information asymmetry to be higher in the alliance. Panel A shows that when a firm from the computer industry forms an alliance, the effect of Fog partner is much stronger, compared to an alliance formed by a firm in the pharmaceutical industry. Panel B shows that when the alliance is between firms from two different industries the effect of Fog_Partner is stronger. Whether the alliance is in the same industry or between different industries is determined based on the Fama-French 48 digit industry classification. The coefficients are from an OLS analysis. Panel C shows that the effect of Fog_Partner is stronger in the pre-SOX period. The control variables are as specified in equation 1 (i.e., all variables used in Column 1 of Panel A in Table 2). All of the continuous variables are winsorized at the 0.5 and the 99.5 percentiles. The variables are defined in the appendix. The ${ }^{* * *},{ }^{* *}$, and $*$ represent significance at the 1,5 , and $10 \%$ levels respectively. The $p$-values are based on standard errors and are in parentheses. 
Table 4: The readability of the partner's annual $10-\mathrm{K}$ report increases the probability of an announced deal being withdrawn before realization

\begin{tabular}{|c|c|c|c|c|}
\hline & (1) & $\begin{array}{c}(2) \\
\text { Dependent variable }=\text { Withdrawn }\end{array}$ & (3) & (4) \\
\hline Fog_partner & $\begin{array}{c}0.0599 \\
(0.008)^{* * *}\end{array}$ & $\begin{array}{l}0.0582 \\
(0.064)^{*}\end{array}$ & & \\
\hline $\begin{array}{l}\text { Average Fog } \\
\text { (of firm and partner) }\end{array}$ & & & $\begin{array}{c}0.0805 \\
(0.028) * *\end{array}$ & $\begin{array}{c}0.0871 \\
(0.030) * *\end{array}$ \\
\hline CAR $(-2,+2)$ firm & & $\begin{array}{c}-0.0644 \\
(0.881)\end{array}$ & & $\begin{array}{l}-0.0296 \\
(0.938)\end{array}$ \\
\hline Control variables & YES & YES & YES & YES \\
\hline Industry Dummies & YES & YES & YES & YES \\
\hline Year Dummies & YES & YES & YES & YES \\
\hline Observations & 3162 & 3162 & 3162 & 3162 \\
\hline Pseudo R-squared & 0.16 & 0.15 & 0.12 & 0.12 \\
\hline
\end{tabular}

Notes on Table 4: This table reports the results of a logit analysis. It shows that the probability of an announced strategic alliance getting withdrawn before realization is higher when the value of Fog_partner is larger. The control variables are as specified in equation 1 (i.e., all variables used in Column 1 of Panel A in Table 2). All of the continuous variables are winsorized at the 0.5 and the 99.5 percentiles. The ***, **, and * represent significance at the 1, 5, and 10\% levels respectively. The $p$-values are based on standard errors clustered by alliance and firm and are in parentheses. All variables are described in Appendix A. 
Table 5: Ruling out alternative explanations

Panel A: Partner's opacity due to earnings management does not affect the cumulative abnormal returns around the strategic alliance's announcement

\begin{tabular}{lcc}
\hline \hline & $(1)$ & $(2)$ \\
& Dependent variable=CAR & $\left(-2,+2 \_f i r m\right.$ \\
Fog_partner & & $\mathbf{- 0 . 0 0 1 8}$ \\
& & $(\mathbf{0 . 0 4 0})^{* *}$ \\
EM_Jones__partner & 0.0201 & 0.0139 \\
& $(0.144)$ & $(0.624)$ \\
Control variables & & \\
& YES & YES \\
Alliance Type Dummies & & \\
Industry Dummies & YES & YES \\
Year Dummies & YES & YES \\
Observations & YES & YES \\
R-squared & 3078 & 3078 \\
\hline
\end{tabular}

Panel B: Main results are not driven by omission of corporate governance variables

\begin{tabular}{|c|c|c|c|c|}
\hline & (1) & (2) & (3) & (4) \\
\hline & \multicolumn{4}{|c|}{ Dependent variable $=C A R(-2,+2) \_$firm } \\
\hline Fog_partner & $\begin{array}{c}-0.0062 \\
(0.041)^{* *}\end{array}$ & $\begin{array}{c}-0.0047 \\
(0.003) * * *\end{array}$ & $\begin{array}{c}-0.0035 \\
(0.039) * *\end{array}$ & $\begin{array}{l}-0.0030 \\
(0.057) *\end{array}$ \\
\hline G-index_partner & $\begin{array}{c}-0.0002 \\
(0.859)\end{array}$ & $\begin{array}{c}-0.0009 \\
(0.525)\end{array}$ & & \\
\hline G-index_firm & $\begin{array}{r}-0.0000 \\
(0.978)\end{array}$ & & & \\
\hline E-index_partner & & & $\begin{array}{c}-0.0016 \\
(0.504)\end{array}$ & $\begin{array}{c}-0.0002 \\
(0.927)\end{array}$ \\
\hline E-index_firm & & & $\begin{array}{r}-0.0009 \\
(0.758)\end{array}$ & \\
\hline \%_Independent_Director_partner & $\begin{array}{l}0.0173 \\
(0.388)\end{array}$ & $\begin{array}{c}0.0169 \\
(0.100)^{*}\end{array}$ & $\begin{array}{l}0.0188 \\
(0.275)\end{array}$ & $\begin{array}{l}0.0095 \\
(0.505)\end{array}$ \\
\hline Number_of_Directors_partner & $\begin{array}{l}0.0016 \\
(0.192)\end{array}$ & $\begin{array}{l}0.0003 \\
(0.750)\end{array}$ & $\begin{array}{l}0.0007 \\
(0.513)\end{array}$ & $\begin{array}{l}0.0006 \\
(0.428)\end{array}$ \\
\hline$\%$ Independent_Director_firm & $\begin{array}{c}0.0467 \\
(0.056)^{*}\end{array}$ & & $\begin{array}{l}0.0252 \\
(0.229)\end{array}$ & \\
\hline Number_of_Directors_firm & $\begin{array}{l}0.0005 \\
(0.639)\end{array}$ & & $\begin{array}{l}0.0003 \\
(0.825)\end{array}$ & \\
\hline Control variables & YES & $\mathrm{NO}$ & YES & $\mathrm{NO}$ \\
\hline
\end{tabular}




\begin{tabular}{lcccc} 
Alliance Type Dummies & YES & NO & YES & NO \\
Industry Dummies & YES & YES & YES & YES \\
Year Dummies & YES & YES & YES & YES \\
Observations & 1396 & 1396 & 1396 & 1396 \\
R-squared & 0.05 & 0.01 & 0.05 & 0.01 \\
\hline
\end{tabular}

Panel C: Main results are robust when we control for managerial ability

\begin{tabular}{lcc}
\hline \hline & $(1)$ & $(2)$ \\
& Dependent variable=CAR $(-2,+2) \_f i r m$ \\
& $\mathbf{- 0 . 0 0 5 0}$ & $\mathbf{- 0 . 0 0 3 4}$ \\
Managerial_ability_partner & $\mathbf{( 0 . 0 0 7 ) * * *}$ & $\mathbf{( 0 . 0 1 5})^{* *}$ \\
& 0.0569 & 0.0043 \\
Managerial_ability_firm & $(0.487)$ & $(0.667)$ \\
& 0.0707 & 0.0073 \\
Industry_adjusted_ROA_firm & $(0.342)$ & $(0.796)$ \\
& -0.1379 & -0.0736 \\
Industry_adjusted_ROA_partner & $(0.000)^{* * *}$ & $(0.001)^{* * *}$ \\
& -0.0020 & -0.0028 \\
Control variables & $(0.817)$ & $(0.713)$ \\
CEO_partner_fixed_effects & & YES \\
CEO_firm_fixed_effects & YES & NO \\
Alliance Type Dummies & YES & NO \\
Industry Dummies & YES & YES \\
Year Dummies & YES & YES \\
Observations & YES & YES \\
R-squared & YES & 2812 \\
\hline Notes & 2812 & 0.06 \\
\hline
\end{tabular}

Notes on Table 5: The control variables are as specified in equation 1 (i.e., all variables used in Column 1 of Panel A in Table 2). All of the continuous variables are winsorized at the 0.5 and the 99.5 percentiles. The $* * *, * *$, and $*$ represent significance at the 1,5 , and $10 \%$ levels respectively. The p-values are based on standard errors clustered by alliance and firm and are in parentheses. All variables are described in Appendix A. 
Table 6: The CAR around the announcement of an alliance is lower for alliances that are withdrawn before realization

Panel A: Equally weighted

\begin{tabular}{lcccc}
\hline \hline Withdrawn & No & Yes & Difference & P-Value \\
CAR (-2,+2)_alliance equally weighted (mean) & 0.0173 & 0.008 & 0.009 & 0.002 \\
CAR (-2,+2)_alliance equally weighted (median) & 0.008 & 0.002 & 0.006 & 0.059 \\
Standard Error & 0.004 & 0.002 & 0.003 & \\
Observations & 1135 & 446 & & \\
\hline
\end{tabular}

Panel B: Value weighted

\begin{tabular}{lcccc}
\hline \hline Withdrawn & No & Yes & Difference & P-Value \\
CAR (-2,+2)_alliance value weighted (mean) & 0.024 & 0.010 & 0.014 & 0.003 \\
CAR (-2,+2)_alliance value weighted (median) & 0.013 & 0.002 & 0.011 & 0.048 \\
Standard Error & 0.004 & 0.002 & 0.005 & \\
Observations & 1135 & 446 & & \\
\hline
\end{tabular}

Notes on Table 6: This table shows that the CAR is smaller for alliances that eventually fail to be realized. CAR $(-2,+2)$ _ alliance equally weighted mean(median) is the average (median) of the CAR for the two firms in the alliance when the alliance is announced. CAR $(-2,+2)$ _alliance value weighted mean(median) is the value weighted (median) CAR for the two firms in the alliance when the alliance is announced. Value weights are based on the market value of the firm. Withdrawn is equal to Yes for those alliances that are withdrawn before the work on the alliance starts, and No is otherwise. The p-values for the average are based on a two-tailed t-test, the p-values for the tests of the medians are based on the Wilcoxon rank sum test. 
Table 7: Readability of the corporate press releases that announce the strategic alliance does not appear to affect the CAR

Panel A: Equally weighted

\begin{tabular}{lccc}
\hline \hline & $(1)$ & $(2)$ & $(3)$ \\
& $D V=C A R$ & $(-2,+2) \_$alliance equally weighted \\
Fog_press_release (equally weighted) & $\mathbf{- 0 . 0 0 2 1}$ & $\mathbf{- 0 . 0 0 1 5}$ & $\mathbf{- 0 . 0 0 1 3}$ \\
& $\mathbf{( 0 . 1 5 4 )}$ & $\mathbf{( 0 . 3 4 8 )}$ & $\mathbf{( 0 . 4 0 1 )}$ \\
Control variables & & & NO \\
& YES & YES & \\
Alliance Type Dummies & YES & NO & NO \\
Industry Dummies & NO & NO & NO \\
Year Dummies & Yes & Yes & Yes \\
Observations & 903 & 903 & 903 \\
R-squared & 0.07 & 0.05 & 0.02 \\
\hline
\end{tabular}

Panel B: Value weighted

\begin{tabular}{lccc}
\hline \hline & $(1)$ & $(2)$ & $(3)$ \\
& $D V=C A R$ & $(-2,+2)$ alliance value weighted \\
Fog_press_release (value weighted) & $\mathbf{- 0 . 0 0 2 7}$ & $\mathbf{- 0 . 0 0 1 9}$ & $\mathbf{- 0 . 0 0 0 9}$ \\
& $\mathbf{( 0 . 1 1 8 )}$ & $\mathbf{( 0 . 2 4 4 )}$ & $\mathbf{( 0 . 5 3 7 )}$ \\
Control variables & YES & YES & NO \\
& & & \\
Alliance Type Dummies & YES & NO & NO \\
Industry Dummies & NO & NO & NO \\
Year Dummies & Yes & Yes & Yes \\
Observations & 903 & 903 & 903 \\
R-squared & 0.07 & 0.05 & 0.02 \\
\hline
\end{tabular}

Notes on Table 7: This table examines the association between the readability of the press releases on the announcement with the CAR. One observation represents one alliance. The results are from an OLS. All variables are value weighted based on the market capitalization. The control variables are as specified in equation 1 (i.e., all variables used in Column 1 of Panel A in Table 2). All of the continuous variables are winsorized at the 0.5 and the 99.5 percentiles. The ***, **, and * represent significance at the 1, 5, and 10\% levels respectively. The $\mathrm{p}$-values are based on standard errors clustered by alliance and firm and are in parentheses. All variables are described in Appendix A. 